\title{
The biabsolutive construction in Lak and Tsez
}

\section{Citation}

Gagliardi, Annie, Michael Goncalves, Maria Polinsky, and Nina Radkevich. 2014. “The Biabsolutive Construction in Lak and Tsez." Lingua 150 (October): 137-170. doi:10.1016/ j.lingua.2014.07.003.

\section{Published Version}

doi:10.1016/j.lingua.2014.07.003

\section{Permanent link}

http://nrs.harvard.edu/urn-3:HUL.InstRepos:33946917

\section{Terms of Use}

This article was downloaded from Harvard University's DASH repository, and is made available under the terms and conditions applicable to Open Access Policy Articles, as set forth at http:// nrs.harvard.edu/urn-3:HUL.InstRepos:dash.current.terms-of-use\#OAP

\section{Share Your Story}

The Harvard community has made this article openly available.

Please share how this access benefits you. Submit a story.

Accessibility 
THE BIABSOLUTIVE CONSTRUCTION IN LAK AND TSEZ

Annie Gagliardi ${ }^{\mathrm{a}}$, Michael Goncalves ${ }^{\mathrm{a}}$, Maria Polinsky ${ }^{\mathrm{a}}$, and Nina Radkevich ${ }^{\mathrm{b}}$

( ${ }^{\mathrm{a}}$ Harvard University and the ${ }^{\mathrm{b}}$ University of York)

\begin{abstract}
In ergative constructions, the agent of a transitive verb is in the ergative case and the theme is in the absolutive case. By contrast, in biabsolutive constructions, both the agent and theme of a transitive verb appear in the absolutive case. This paper presents and analyzes the biabsolutive construction in two Nakh-Dagestanian languages, Lak and Tsez. Despite many surface similarities, the biabsolutive constructions in Lak and Tsez call for different syntactic analyses. We argue that the biabsolutive construction in Lak is an instance of restructuring in the presence of an aspectual head bearing a progressive (imperfective) feature. Tsez biabsolutive constructions, on the other hand, are biclausal; we argue that the theme and the lexical verb are contained in a PP complement selected by a light verb. Related languages may be classified as "Lak-type" or "Tsez-type" based on the behavior of their biabsolutives. The existence of two underlying structures for one surface pattern in Nakh-Dagestanian poses a learnability problem for a child acquiring a language with biabsolutive constructions. We outline a set of strategies used by a learner who must compare the available input data with a set of structural hypotheses.
\end{abstract}

Keywords: ergative, absolutive, biabsolutive, noun class agreement, restructuring, separate clausal domains, structural ambiguity, control; Nakh-Dagestanian languages, Lak, Tsez 
THE BIABSOLUTIVE CONSTRUCTION IN LAK AND TSEZ

\section{$1 \quad$ Introduction $^{1}$}

In a number of Nakh-Dag(h)estanian (ND) languages, a contrast exists between transitive constructions in which the subject (the agent of the event) is in the ergative case and the object (theme) is in the absolutive, (1), and constructions in which both core arguments appear in the absolutive case, (2).

(1) A Ali-1 čawaxulu t'it'laj b-ur. Lak

Ali-ERG window.III.SG.ABS III.open.PROG III-AUX

'Ali is opening a/the window.'

(2)
$\mathrm{A}^{\mathrm{f}} \mathrm{li}-\varnothing \quad$ čawaxulu
t'it'laj
$\varnothing$-ur.

Ali-I.ABS window.III.SG.ABS III.open.PROG I-AUX

'Ali is opening a/the window.'

The latter construction is known as the biabsolutive (see Forker 2012 for an overview) or binominative (Kibrik 1975). These differences in case marking are accompanied by different agreement patterns: in (1), both verbs agree with the absolutive theme, while in (2), the auxiliary 'be' agrees with the agent absolutive.

\footnotetext{
${ }^{1}$ Unless otherwise indicated, language examples are from the authors' field notes. The abbreviations used in the glosses follow the Leipzig glossing rules. Additional abbreviations: AOR - aorist, ASSRT - assertive, CONTR - contrastive, EVID - evidential, GER - gerund, MSDR-masdar, NONEVID — non-evidential, OS — oblique stem; POTpotential. Roman numerals in the glosses indicate noun class agreement, and Arabic numerals indicate person agreement. Because noun class agreement occurs only with the absolutive, we indicate only the class of absolutive arguments in the glosses.
} 
This paper presents and analyzes the biabsolutive construction in two ND languages, Lak (lbe) and Tsez (also known as Dido, ddo). In choosing to examine these particular languages, we pursue two related goals. Our first goal is descriptive. The biabsolutive construction is widely attested in ND languages; with the exception of some Lezgic languages such as Rutul, Kryz, Budukh (Forker 2012), and Tabasaran (Natalia Bogomolova, p.c.), all languages of the family exhibit this construction. However, except for Archi (Kibrik 1975) and Avar (Harris \& Campbell 1995), there are few detailed descriptions of the construction in individual languages. By focusing on Lak and Tsez in greater detail, we hope to stimulate similar descriptive work within other languages of the family.

Our second and principal goal is to develop a syntactic analysis of the biabsolutive construction. We use the comparison between Lak and Tsez to demonstrate that superficial similarities between biabsolutive constructions in different languages may actually mask different syntactic structures. We conclude that the syntactic structure of the biabsolutive construction varies across ND languages; however, within a particular language, the construction receives a consistent analysis that connects all the surface properties in a principled way. This analysis breaks from Forker's (2012) proposal, in which a prototypical biabsolutive construction is characterized by a cluster of properties, each of which a given member of the family may or may not exhibit.

The paper is organized as follows. In section 2, we present a brief overview of the syntax of Lak and Tsez and introduce the main properties of biabsolutive constructions in these two languages. In section 3, we propose an analysis of certain case and agreement 
facts in Lak and Tsez that will serve as a basis for our account of the biabsolutive construction. In sections 4 and 5, we propose that Lak and Tsez biabsolutives require two different analyses. In particular, we argue in section 4 that Lak biabsolutives have a monoclausal structure; we attribute the appearance of the second absolutive-marked argument in the Lak construction to the lack of an [ERG] case feature and the concomitant presence of an additional aspectual feature on the $v$ head. By contrast, in section 5 we propose that Tsez biabsolutives involve a PP complement selected by a light verb. The latter analysis is similar to the analysis of biabsolutive constructions offered for Basque (Laka 2006); we discuss the parallels between the Tsez and Basque analyses in section 6.

In section 6, we also evaluate the pseudo noun incorporation analysis of the biabsolutive construction proposed by Forker $(2009 ; 2012)$ against the data from Lak and Tsez introduced in this paper, and show that Forker's analysis cannot fully capture all the facts. In section 7, we take up several outstanding issues, concluding that at least some restrictions on biabsolutive constructions are semantic, rather than syntactic, in nature. The existence of multiple possible syntactic structures underlying a superficially similar biabsolutive construction in different languages introduces a potential learnability problem, which we also address in section 7. Section 8 presents our conclusions.

\section{Overview of Lak and Tsez clause structure}

Nakh-Dagestanian, also known as Northeast Caucasian, is a family of languages spoken in the northern Caucasus region of the Russian Federation, between the Caucasus Mountains and the Caspian Sea. The family includes the Nakh branch (Chechen, Ingush, 
and Batsbi) and the Dagestanian languages, which include several genetic subgroups. In this paper, we specifically investigate two of these languages. Lak alone constitutes the Lak subgroup of the family; it is spoken by roughly 153,000 people, mostly living in the Republic of Dagestan, with smaller groups of speakers in Central Asia, Azerbaijan, Ukraine, and Turkey (Lewis et al. 2013). The Lak data presented in the paper were collected from speakers of the Kumukh dialect. Tsez belongs to the Tsezic subgroup of the Dagestanian languages and is spoken by 12,500 people in the Tsuntinsky District in the Republic of Dagestan, as well as in Georgia and villages along the Caspian Sea (Lewis et al. 2013); heritage speakers of Tsez also live in Turkey.

ND languages are quite diverse but share a number of similarities, including headfinal characteristics, morphological ergativity, and verbal agreement in noun class (grammatical gender) with the absolutive argument. In section 2.1, we discuss these properties in detail, as they are important for understanding biabsolutive constructions. In section 2.2, we introduce key facts about the biabsolutive construction, including the case and agreement patterns, interpretive differences between biabsolutive and ergative constructions, and the apparent optionality of biabsolutives.

\subsection{Basics of Lak and Tsez grammar}

\subsubsection{Morphology and word order}

Lak and Tsez are both ergative languages - i.e., languages in which the subjects of intransitive verbs pattern with the objects of transitive verbs in terms of agreement - as

illustrated in examples (3)-(4) from Lak and (5)-(6) from Tsez. Both languages are head- 
final, exhibiting postpositions and prenominal relative clauses. Like other ND languages, they are heavily pro-drop: both core arguments are often omitted. ${ }^{2}$

a. But:a $\varnothing$-i:zundi.

Lak

father.I.ABS I-got.up

'Father got up.' (Kibrik 2003: 466)

b. Ninu d-i:zundi.

mother.II.ABS II-got.up

'Mother got up.'

(4)

a. But:a-1 ninu d-uručlaj d-ur.

father-ERG mother.II.ABS II-protect.PROG II-AUX

'Father protects/is protecting mother.'

b. Nit:i-1 but:a $\varnothing$-uručlaj $\varnothing$-ur.

mother.II-ERG father.I.ABS I-protect.PROG I-AUX

'Mother protects/is protecting father.'

(5)

$\begin{array}{lll}\text { a. Tušman } \varnothing \text {-ay-s(i) }{ }^{3} & \text { Tsez }\end{array}$

enemy.I.ABS I-come-PST.EVID

'The enemy came.'

${ }^{2}$ Statistics on argument drop in Lak and Tsez are not presently available. However, in Avar, a related ND language, intransitive subjects are dropped $47 \%$ of the time, transitive subjects are dropped $70 \%$ of the time, and absolutive objects are dropped $5 \%$ of the time (Polinsky et al. 2012).

${ }^{3}$ Depending on the dialect, the final vowel may be omitted from verb forms whose stem ends in a glide; we indicate this variation by placing the optional vowel in parentheses. See Bokarev (1959: 209), Imnajšvili (1963: 24-27, 177-183), and Comrie (1997; 2001). 
b. ${ }^{\varsigma} \mathrm{Al} \quad$ b-ay-s(i).

strength.III.ABS III-come-PST.EVID

'Strength increased (came).'

(6)

a. Už-ā kid y-iqir-si.

boy-ERG girl.II.ABS II-catch- PST.EVID

'The boy caught the girl'.

b. Kid-bā uži $\quad \varnothing$-iqir-si.

girl-ERG boy.I.ABS I-catch- PST.EVID

'The girl caught the boy.'

Despite their head-final nature, Lak and Tsez show relatively free word order in the matrix clause, as illustrated in (7) for Lak; see Comrie et al. (1998), Polinsky \& Potsdam $(2001,2002)$ for Tsez.
a. A $^{\complement} \mathrm{li}-1$ arcu
ars-na-č'an
t'ajla d-uklaj ${ }^{4}$
d-ur. $\quad L a k$
Ali-ERG money.IV.ABS son-OS-LAT send IV-leave.PROG IV-AUX
'Ali sends money to his son.'
b. A Ali-1 ars-na-č'an t'ajla d-uklaj d-ur arcu.
Ali-ERG son-OS-LAT send IV-leave.PROG IV-AUX money.IV.ABS
c. Arcu A $\mathrm{f}^{\mathrm{l}} \mathrm{i}-\mathrm{l}$ ars-na-č'an t'ajla d-uklaj d-ur.
money.IV.ABS Ali-ERG son-OS-LAT send IV-do.PROG IV-AUX

\footnotetext{
${ }^{4}$ The Lak verb 'send' is a complex verb, which consists of two parts: tajla, a short form of the adjective t'ajlas:a 'straight, even', and (d)uk:an 'leave (intransitive)' (Khaidakov 1962: 259-260).
} 
Embedded clauses, on the other hand, exhibit a rigid verb-final word order. Consider the contrast between (7) and (8) in Lak; see Polinsky \& Potsdam $(2001,2002)$ for data from Tsez. ${ }^{5}$

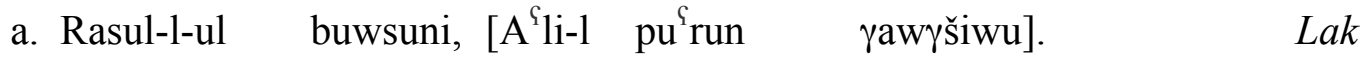

Rasul-OS-ERG said, Ali-ERG glass.IV.ABS broke.IV

'Rasul said that Ali broke the window.'

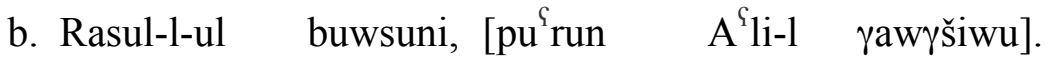

Rasul-OS-ERG said, glass.IV.ABS Ali-ERG broke.IV

c. *Rasul-1-ul buwsuni, [A [A li-1 yawyšiwu pu ${ }^{\complement}$ run].

Rasul-OS-ERG said, Ali-ERG broke.IV glass.IV.ABS

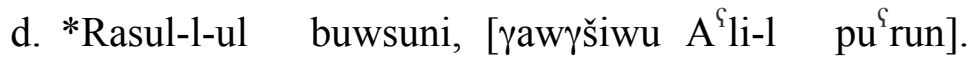

Rasul-OS-ERG said, broke.IV Ali-ERG glass.IV.ABS

Both languages have a rich system of (finite and non-finite) verbal forms; we will not describe them comprehensively, focusing only on those forms that are relevant for the discussion below. In Lak, different tense-aspect-mood distinctions are expressed through morphophonological alternations, such as vowel changes in the stem, reduplication, and infixation (see Khaidakov 1966, El'darova 1995, Sylak 2008). For alternations in Tsez verb stems, see Bokarev (1959: 203-217), Imnajšvili (1963: 163-183), Comrie (1997),

${ }^{5}$ Unlike Tsez, Lak allows VP-fronting in embedded clauses, which results in the verb being a non-final element in the clause, as in (i). In such contexts, the constituent appearing on the right (the agent, in (i)) is interpreted as the clausal topic.

(i) Rasul-1-ul buwsuni, pu ${ }^{\complement}$ run $\quad$ jaw $\gamma$ šiwu $\mathrm{A}^{\mathrm{\complement}} \mathrm{li}-1 . \quad$ Lak Rasul-OS-ERG said, glass.IV.ABS broke.IV Ali-ERG 'Rasul said that Ali, he broke the window.' 
and Comrie et al. (1998).

\subsubsection{Agreement}

ND languages vary with respect to the number of noun classes (genders) they preserve, ${ }^{6}$ from two in Tabasaran to eight in Batsbi. In Lezgian (Haspelmath 1993), Aghul (Magometov 1970), Udi (Harris 2002), and some dialects of Tabasaran (Magometov 1965), noun classes are absent altogether. Both Lak and Tsez have four noun classes. Their noun class systems reflect a mix of gender, animacy, and number features (for discussion, see Polinsky \& Jackson 1998, Gagliardi \& Lidz 2014, Plaster et al. 2013).

Tables 1 and 2 show Lak and Tsez class exponents, which are revealed in agreement. Lak agreeing forms differ with respect to inflection for noun class: some verbs take prefixes, while others take infixes (Khaidakov 1966). Tsez verbs and adjectives always take agreement prefixes. However, not all verbs/adjectives show overt class agreement. The basic generalization is that class agreement prefixes never surface on verbs/adjectives with initial consonants; agreement is overtly marked only on a subset of vowel-initial verbal/adjectival stems, though the conditions blocking agreement on some vowel-initial stems remain unclear (see Kibrik \& Kodzasov 1988; Comrie et al. 1998, for some considerations regarding possible blocking factors).

\footnotetext{
${ }^{6}$ The term 'noun class' is traditionally used in the description of noun classifications in $\mathrm{ND}$, and we will follow this convention here.
} 
Table 1. Lak noun class agreement markers (Sylak 2008: 13)

\begin{tabular}{|l|l|l|l|l|l|}
\hline $\begin{array}{l}\text { Class, } \\
\text { singular }\end{array}$ & Prefix & Infix & Class, plural & Prefix & Infix \\
\hline I & $\varnothing-$ & -w- & I, II, III & b- & -w- \\
\hline III & b- & -w- & IV & d- & -r- \\
\hline II, IV & d- & -r- & \multicolumn{3}{|l}{} \\
\cline { 1 - 3 }
\end{tabular}

Table 2. Tsez noun class agreement markers (Polinsky \& Jackson 1998)

\begin{tabular}{|l|l|l|l|}
\hline $\begin{array}{l}\text { Class, } \\
\text { singular }\end{array}$ & Prefix & Class, plural & Prefix \\
\cline { 1 - 2 } I & $\varnothing-$ & I & b- \\
\hline II & y- & II-IV & r- \\
\cline { 1 - 2 } III & b- & \multicolumn{2}{|l}{} \\
\cline { 1 - 2 } IV & r- & &
\end{tabular}

Both lexical and auxiliary verbs show noun class agreement only with absolutive arguments. ${ }^{7}$

\subsubsection{Clauses with one-place and two-place predicates}

This section presents an overview of case marking in intransitive and transitive clauses.

Within Tsez intransitive verbs, unergatives can be distinguished from unaccusatives in that only unergatives form iteratives (see Comrie \& Polinsky 1999b, and see example (51) below). Diagnostics for unaccusativity in Lak are not known, but we present some examples that follow the typical semantics for unergatives (9) and unaccusatives (10). Regardless of putative unaccusativity, all intransitive verbs take an absolutive argument

7 In addition to noun class agreement, Lak also has a person agreement system (Khaidakov 1966; Radkevich \& Clemens 2013). Person agreement is a rare phenomenon in ND, and one we will not be concerned with here. 
and show surface agreement with that argument if the morphophonological factors cooperate; thus, there is no split intransitive marking.

$$
\mathrm{Na} \quad \varnothing \text {-izlaj } \varnothing \text {-ur. }
$$

Lak

1SG.I.ABS I-get.up.PROG I-AUX

'I am getting up.'

(10)

Ninu d-awxun-di.

mother.II.ABS II-fell-3

'Mother fell down.'

(11) Uži c'ok'inay-s(i).

Tsez

boy.I.ABS swear-PST.EVID

'The boy swore.'

Eniy $\quad y$-izi-s.

mother.II.ABS II-rise-PST.EVID

'Mother rose to her feet.'

Two-place predicates form three main types of constructions: ergative (transitive), affective (sometimes referred to as the "dative construction"), and biabsolutive (see Comrie 2000; Comrie \& van den Berg 2006 for an overview). The ergative construction was illustrated in examples (4) and (6) above: the higher argument receives ergative case, the lower argument receives absolutive case, and both lexical and auxiliary verbs agree with the absolutive argument. In the affective construction, the higher argument is marked with the dative or locative case and bears an experiencer (affectee) theta role; such constructions are commonly found with psych-verbs and with potential/optative 
verb forms. In the affective construction, as in the ergative construction, the verb agrees with the absolutive argument. This is shown in (13) and (14).

(13) T:u-n ga k:awk:-un-di.

Lak

1SG-DAT he.I.ABS I.see-AOR-3

'I saw him.' (Kibrik 2003: 465)

(14) Kid-ber uži $\varnothing$-eti-x

Tsez

girl-DAT boy.I.ABS I-like/love/want-PRS

'The girl loves the boy.'

Lexical and auxiliary verbs agree in noun class with the absolutive argument, but never with the dative or ergative argument.

\subsubsection{Ergative and dative in the $v P$ structure}

Data from binding and control illustrate that ergative arguments are structurally higher than absolutive objects. In the following pair of sentences from Lak, ergative arguments can bind absolutive anaphors, but not vice versa. ${ }^{8}$

a. Rasul-l-ul $\quad$ (cala) cuwa cut $_{\mathrm{i}}$ awt-un-ni.

Lak

Rasul-OS-ERG self.ERG self.I.ABS I.beat-PST-3

'Rasul beat himself up.'

b. *(Cala) cala $_{\mathrm{i}} \quad$ Rasul $_{\mathrm{i}} \quad$ awt:-un-ni. self.ERG self.ERG Rasul.ABS I.beat-PST-3

\footnotetext{
${ }^{8}$ For similar facts on Tsez binding, see Comrie \& Polinsky (1999c), Polinsky \& Comrie (2003).
} 
In Tsez, all reflexive forms must be compounds (in contrast, the compound form in Lak is optional, as shown in (15)a). The first part of the compound reflexive is homophonous with the ergative, as in Lak. The second part matches the case of the bound argument (Polinsky \& Comrie 2003). Ergative reflexive forms of the type illustrated in (16) simply do not exist.

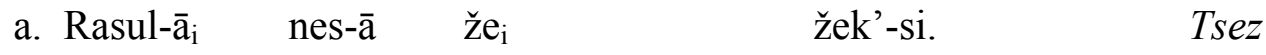

Rasul- ERG [self-ERG self-ABS].REFL.ABS hit-PST.EVID

'Rasul beat himself up.'

b. *nes-āa nes-āa

[self.ERG self-ERG].REFL.ERG Rasul.ABS hit-PST.EVID

Under obligatory control, only the ergative argument (and, if volitionality can be inferred, the dative argument) of a transitive verb can be targeted (see Polinsky \& Potsdam 2002 for a detailed discussion). Superiority effects also point to a higher structural position for the ergative (Polinsky \& Potsdam 2001: 631).

With respect to dative arguments, we need to distinguish between dative experiencer subjects and all other dative arguments. The former appear in the affective construction, where the dative experiencer argument combines with a psych-verb predicate, as illustrated in (15) and (16) above. Lak and Tsez differ with respect to the binding relationship between the dative and the absolutive in the affective construction. In Lak, the dative experiencer argument behaves like the ergative: it can bind absolutive anaphors, but not be bound by them (17). In Tsez, however, the dative and absolutive can 
bind one another in either direction, as shown in (18) (see also Comrie \& Polinsky 1999c; Polinsky \& Comrie 2003).
a. But:a-n $\mathrm{n}_{\mathrm{i}} \quad$ cuwa $_{\mathrm{i}} \quad$ dahant:uwa k:awk:un-di.
Lak father.I-DAT REFL.I.ABS in.mirror I.saw-3

'Father saw himself in the mirror.'

b. *But: $a_{\mathrm{i}} \quad$ ca-n $=\varnothing-\mathrm{a}_{\mathrm{i}}$ dahant:uwa k:awk:un-di. father.I.ABS REFL-DAT-I in.mirror I.saw-3

$\begin{array}{llll}\text { a. } \operatorname{Irbahin}_{\mathrm{i}} \quad \text { nes-ā nesi-r } \mathrm{r}_{\mathrm{i}} & \varnothing \text {-eti-x-ānu. }\end{array}$ Ibrahim.I.ABS [self-ERG self-DAT].REFL.DAT I-like-PRS-NEG 'Ibrahim does not like himself.'

b. Irbahin-er ${ }_{i} \quad$ nes-āa $\quad \check{z ̌ e}_{\mathrm{i}} \quad \varnothing$-eti-x-ānu. Ibrahim-DAT [self-ERG self-ABS]REFL.ABS I-like-PRS-NEG 'Ibrahim does not like himself.'

The alternation illustrated in (18)a,b is only found with psych-verbs in Tsez. Based on these facts, we suggest that Tsez (but not Lak) permits the experiencer theta role of a psych-verb to map to either the dative or the absolutive argument. Such differential mapping is reminiscent of the familiar fear/frighten alternation in English (Belletti \& Rizzi 1988, a.o.), where the experiencer can map to either the subject position (fear) or to the object position (frighten). In each case, the logic of the comparison is the same: the experiencer argument is either in a relatively high structural position (from which it can bind the absolutive) or in a lower structural position, that of an internal argument. The 
differential mapping of the experiencer argument in Tsez will not come into play in the discussion below, so the structure we propose in (20) is sufficient for our purposes.

To summarize, the ergative argument is structurally higher in the derivation than the absolutive argument, as schematized in (19).

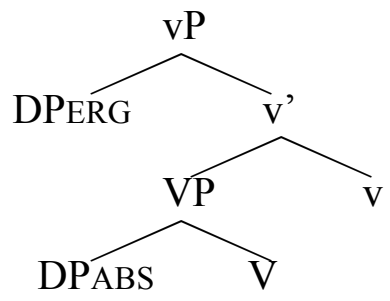

The dative used with psych-verbs, an inherent case whose use is limited to a handful of predicates, is licensed in the same position as the ergative. The structure in (19) captures the Lak binding facts in (17) and the Tsez binding facts in (18)a; we assume that dative subjects, which occur in complementary distribution with ergative subjects, are always licensed in spec, $v \mathrm{P}$ in Lak, and are licensed in that positon for the fear-type verbs in Tsez.

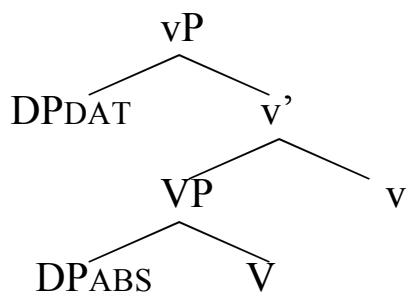

Lak; Tsez (fear-type verbs)

Dative objects in ND languages cannot bind the ergative, but can be bound by it, as shown in (21) and (22) for Lak and Tsez, respectively.

a. $G^{\mathrm{w}} \mathrm{a}-\mathrm{na}-\mathrm{l}_{\mathrm{i}} \quad$ ca-nba $a_{\mathrm{i}} \quad$ q'a ${ }^{\mathrm{c}} \mathrm{p}: \mathrm{a} \quad$ lawsun-di. Lak

3SG-OS-ERG REFL-DAT.III hat.III.ABS III.buy-3

'He bought himself a hat.' (Kibrik 2003: 477-478) 
b. ${ }^{*} \mathrm{Ca}-\mathrm{lba}_{\mathrm{i}} \quad \mathrm{g}^{\mathrm{w}} \mathrm{a}-\mathrm{na}-\mathrm{n}_{\mathrm{i}} \quad$ q'a ${ }^{\mathrm{q}} \mathrm{p}: \mathrm{a} \quad$ lawsun-di.

REFL-ERG.III 3SG-OS-DAT hat.III.ABS III.buy-3

(22)
a. $U \check{z}-\bar{a}_{i}$
nes-ā nesi- $r_{i}$
marožni
r-is-si.
Tsez

boy-ERG [self-ERG self-DAT].REFL.DAT ice-cream.ABS IV-buy-PST.EVID

'The boy bought himself ice cream.'

b. *uži-r $r_{i}$ nes-ā mes-ā marožni r-is-si.

boy-DAT [self-ERG self-ERG].REFL.ERG ice-cream.ABS IV-buy-PST.EVID

Similarly, dative objects can bind the absolutive but cannot be bound by it, as shown below (this binding asymmetry does not depend on the order of the two objects): ${ }^{9}$

$\begin{array}{lllll}\text { a. Eniy-āa ňibaw uži- } \mathrm{r}_{\mathrm{i}} \quad \text { nes-ā } & \text { nesi-s } \mathrm{s}_{\mathrm{i}} & \text { Tsez }\end{array}$ mother-ERG each boy-DAT [self-ERG self-GEN1].REFL.GEN1

k'etu tex-si.

cat.ABS give-PST.EVID

'Mother gave each boy his $_{i}$ cat.'

b. *eniy-ā šibaw k'etu $\mathrm{i}_{\mathrm{i}}$ nełā neło- $\mathrm{z}_{\mathrm{i}}$

mother-ERG each cat.ABS [self-ERG self-GEN2].REFL.GEN2

uži-r tex-si.

boy-DAT give-PST.EVID

${ }^{9}$ As mentioned above, Tsez has four noun classes, but Tsez reflexives only distinguish between class I (male referents) and all other classes (II-IV); see Polinsky \& Comrie (2003: 271). In (23)a, the reflexive belongs to class I because $u z ̌ i ~ ' b o y '$ is class I. In (23)b, the reflexive could be coindexed with either the object 'cat' (class III) or the subject 'mother' (class II). The irrelevant reading (where the reflexive is coindexed with 'mother') is possible, but the crucial reading where the reflexive is coindexed with the object 'cat' is impossible. 
('Mother gave each cat to its boy-owner.')

These facts indicate that dative objects are licensed in a lower $\nu \mathrm{P}$, as is standardly assumed for ditransitives (Larson 1988; 1990); the structure in (24) straightforwardly accounts for the binding facts in (22) and (23):

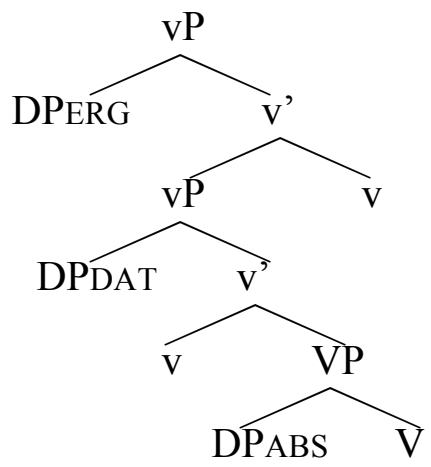

\subsection{The biabsolutive construction}

Besides the transitive constructions discussed above, where the highest argument is either dative- or ergative-marked and the lower argument is absolutive, most ND languages have a biabsolutive construction, where both arguments are marked with the absolutive. In this section, we present the core properties of this construction.

\subsubsection{Ergative vs. biabsolutive}

The biabsolutive has a different case and agreement pattern from the canonical ergative construction. Consider the following sentences: (25)a is an example of a regular ergative construction in Lak; in $(25) \mathrm{b}$, however, the agent is marked with the absolutive rather than ergative case. The two sentences in (26) illustrate the same ergative/biabsolutive contrast for Tsez. 


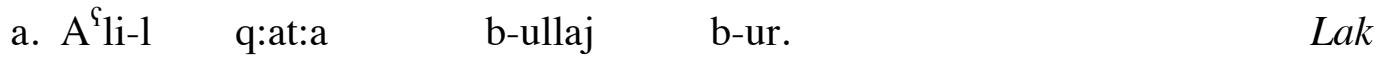

Ali-ERG house.III.ABS III-do.PROG III-AUX

'Ali is building a house.'

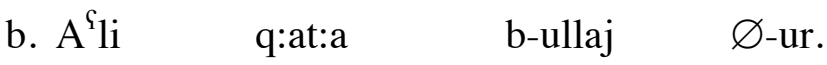

Ali.I.ABS house.III.ABS III-do.PROG I-AUX

'Ali is building/in the state of building a house.'

a. ${ }^{\complement} \mathrm{Al}-\overline{\mathrm{a}} \quad \mathrm{y}^{\varsigma} \mathrm{utku} \quad$ r-oy-s(i). Tsez

Ali-ERG house.IV.ABS IV-make-PST.EVID

'Ali built a house.'

b. ${ }^{\complement}$ Ali $\quad \gamma^{\varsigma} u t k u \quad$ r-oy-x(o) $\quad \varnothing$-ičā-si $\quad$ (zow-s(i)).

Ali.I.ABS house.IV.ABS IV-make-XO I-stay-RES be-PST.EVID

'Ali was building/was in the state of building a house.'

Agreement in the biabsolutive construction also differs from that found in the ergative. It is the absolutive DP that controls agreement in the ergative and dative constructions, while dative and ergative arguments can never participate in class agreement. In the biabsolutive construction, on the other hand, the lexical verb shows agreement with the lower absolutive argument (the theme), while auxiliary verbs agree with the higher absolutive (the agent or agent-like argument). Combining all these facts, the case and agreement patterns for ND are illustrated in (27): agreement on the lexical verb is 
controlled by the theme (in a box), while the auxiliary shows agreement with the agent (underlined). ${ }^{10}$

$$
\begin{array}{clllll}
\text { Žek'u } & \text { bišwa } & \text { r-ac'-xo } & \varnothing \text {-ič-asi } & \text { (yoł) } & \text { Tsez } \\
\text { man.I.ABS } & \text { food.IV.ABS } & \text { IV-eat-Xo } & \text { I-stay-RES } & \text { be.PRS } &
\end{array}
$$

'The man is engaged in eating food.'

The ergative/dative and biabsolutive constructions also contrast with respect to clause specifications for tense-aspect-mood (TAM): ergative/dative constructions are available in all TAM combinations, whereas the biabsolutive construction only occurs in the imperfective or progressive aspect. ${ }^{11}$ However, biabsolutives are not obligatory in Lak and Tsez progressives. Consider the following minimal pair.
A 1 li-1 $\quad$ q:at:a
b-ullaj
b-ur.
Lak

Ali-ERG house.III.ABS III-do.PROG III-AUX

'Ali is building the house.'
$\mathrm{A}^{\complement} \mathrm{li}$
q:at:a
b-ullaj
$\varnothing$-ur.

Ali.I.ABS

house.III.ABS III-do.PROG I-AUX

'Ali is in the state of building a house (=house-building currently affects his life).'

${ }^{10}$ In cases involving multiple auxiliaries, all auxiliaries agree with the highest absolutivemarked argument, as shown in (i).

(i) Amma harajzu ... duš cama-na-n b-ulun čaj $\quad$ Lak but millner.I.ABS girl.III.ABS another-OS-DAT III-give.away.INF want.PRG $\varnothing$-us:a $\varnothing$-ur. I-AUX.PRT I-AUX

'They say that the mill owner wants to give the girl away to another man.'

(Kazenin 2013: 61)

${ }^{11}$ Kazenin (1998) shows that Lak also allows biabsolutives in perfective contexts when a completed event is viewed as having an effect on or consequences for the agent. 
The meanings of (28) and (29) are similar; however, the second sentence emphasizes the fact that the agent referent is in the state of building the house and that this state of affairs has an effect on the agent. Both sentences are perfectly grammatical, which means that the imperfective/progressive is compatible with both constructions.

Besides the properties discussed above, the biabsolutive is also distinguished from the ergative based on certain pragmatic properties. In particular, Forker (2012) shows that animate subjects are preferred in the biabsolutive construction, while no animacy restriction on agents is found in the ergative construction. In addition, the biabsolutive construction denotes a state of affairs that primarily affects the agent (according to Forker 2012: 80, the "agent is the semantic centre of the construction"). Researchers also suggest that typical functions of the biabsolutive construction include emphasis on the state of the agent and concomitant patient demotion (Kazenin 1998; Forker 2012). The foregrounding of the agent referent (what Forker refers to as "agent focusing") goes hand-in-hand with the perception of the agent as affected by the ongoing state of affairs denoted by the construction. In our analysis, we will concentrate on the structural aspects of the biabsolutive construction; as a result, some of these interpretive properties will not be fully explored.

\subsubsection{Contrasts between Lak and Tsez with respect to biabsolutives}

Despite the similarities presented above, there are several clear differences between Lak and Tsez biabsolutives - namely, the morphology of the predicate, the range of constructions that alternate with the biabsolutive, and the possibilities for extraction. 


\subsubsection{Morphology of the predicate}

The first contrast between the Lak and Tsez biabsolutives has to do with the morphological build-up of the predicate in this construction. In both languages, tense and aspect can be encoded synthetically, within the verb form, or analytically, with the use of auxiliaries. ${ }^{12}$ Compare the Lak synthetic verb form in (3) above to the Lak analytic form in (1)-(2). The synthetic form in Tsez was illustrated in numerous exampes above, including (5), (6), (18), and (22)a; the analytic form is shown in example (30) below, where the auxiliary 'be' (past tense stem zow-) combines with the imperfective gerund. ${ }^{13}$

$\begin{array}{llll}\text { Už-ā } \quad \text { kid } \quad \text { k'ik'ek'-xo } & \text { zow-s(i). } & \text { Tsez }\end{array}$ boy-ERG girl.II.ABS tease-GER be-PST.EVID

'The boy was teasing/ridiculing the girl.'

The gerundial form in (30) is particularly relevant for our discussion because it is homophonous not only with the present tense finite form ending in $-x(o)$ (Bokarev 1959: 210ff.; Imnajšvili 1963: 176-179), but also with the form found in the biabsolutive construction. We defer further discussion of this form until section 4.2.

\footnotetext{
${ }^{12}$ We adopt the terminology used in Kazenin (1998) and Kibrik (2003), among others, which distinguishes between synthetic and analytic TAM forms based on the presence/absense of a free-standing auxiliary. An anonymous reviewer points out that Lak synthetic forms contain suffixes that look identical to the person agreement segments of copulas, thus making the distinction between synthetic and analytic forms less clear. There are different views on this problem; for example, Burčuladze (1979: 224-226) uses phonological evidence to suggest that synthetic forms in Lak are synchronically distinct from analytic forms, although diachronically they go back to the same source. Nothing in our analysis hinges on the distinction between the two types of TAM forms of Lak verbs. ${ }^{13}$ The construction in (30) is monoclausal; it can only have a single negation and single adverbial modification.
} 
In Lak, the predicates of the ergative and biabsolutive constructions can exhibit the same morphological patterns (modulo differences in agreement). Compare the synthetic TAM form in the ergative clause in (31)a, to the biabsolutive one in (31)b:

a. Ga-n-al na uhlahi-s:a-ra.

3SG-OS-ERG 1SG.I.ABS catch.I.PROG-ASSRT-1SG

'He is catching me.'

b. Ga na uhlahi-s:a-r.

3SG.ABS 1SG.I.ABS catch.I.PROG-ASSRT-3SG

'He is catching me.' (Kazenin 2013: 59)

In Tsez, on the other hand, the predicate of the biabsolutive construction is always analytic. Thus, (32)a below is ungrammatical. The biabsolutive predicate contains three parts: a lexical verb ending in $-x o$, which agrees with the theme absolutive; ${ }^{14}$ the resultative participle of the verb -iča 'stay', which agrees with the agent absolutive; the auxiliary (which can be omitted) ${ }^{15}$ No agreement occurs on the consonant-initial auxiliary; recall that only vowel-initial stems take agreement prefixes in Tsez.

$\begin{array}{llll}\text { a. *uži kid k'ik'ek'-xo (yoł). } & \text { Tsez }\end{array}$

boy.I.ABS girl.II.ABS tease-XO be.PRS

('The boy is teasing/ridiculing the girl.')

\footnotetext{
${ }^{14}$ In section 4.2.1, we will discuss the status of the form in $-x o$ and show that it is not the same as the gerund in (30), (32)a; for now, we will be simply glossing it as $-X O$.

${ }^{15}$ Auxiliaries can be dropped freely anywhere in Tsez, not just in the biabsolutive construction. The resultative participle of -iča can be dropped in sentence fragments.
} 
b. Uži kid k'ik'ek'-xo Ø-ičāsi yoł.

boy.I.ABS girl.II.ABS tease-XO I-stay-RES be.PRS

'The boy is teasing/ridiculing the girl.'

To summarize, Tsez biabsolutive constructions always have an analytical predicate, whereas Lak allows both synthetic and analytic verb forms in the biabsolutive.

\subsubsection{Alternation with non-biabsolutive constructions}

Another distinction between Lak and Tsez has to do with the range of constructions that can alternate with the biabsolutive. Recall that, in addition to the ergative construction, Lak and Tsez each have an affective construction, containing an experiencer subject, and a potential construction, whose subject surfaces in a spatial case.

For at least some speakers of Lak, the affective construction has a possible biabsolutive counterpart, as shown in (33)b (one of our language consultants accepted this sentence, whereas the others rejected it). Lak is rather unusual in this respect; few ND languages allow affective (experiencer) verbs to appear in the biabsolutive construction (see also Forker 2012: 78, 82-83; Kazenin 2013: 67, 197).

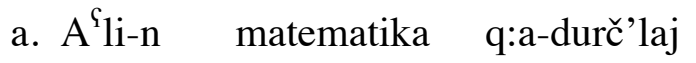
d-ur.
Lak
Ali-DAT math.IV.AB
NEG-understand.PROG
IV-AUX
'Ali does not understand math.'
b. \%A $\mathrm{A}^{\mathrm{fli}}$ matematika q:a-durč'laj $\varnothing$-ur.
Ali.I.ABS math.IV.ABS NEG-understand.PROG I-AUX
'Ali does not understand math.' 
In Tsez, biabsolutive variants of affective constructions with an experiencer subject are impossible:

$\begin{array}{llll}\text { a. Kid-ber keč' tax'i-x. } & \text { Tsez }\end{array}$ girl-DAT poem.III.ABS forget-PRS

'The girl forgot the poem.'

b. *Kid keč $\quad$ lax'i-x y-ičā-si (yol). girl.II.ABS poem.III.ABS forget-XO II-stay-RES be.PRS ('The girl is in the state of having forgotten the poem.')

Likewise, Tsez potential constructions, in which the subject appears in one of the spatial case forms (Comrie 2000; Comrie et al. 1998), cannot alternate with the biabsolutive:

$\begin{array}{lll}\text { a. Yedu kid-beq ziya b-izir-oł. Tsez } & \end{array}$ this girl-LOC cow.III.ABS. III-lift-POT

'This girl can lift a cow.'

b. *Yedu kid ziya b-izir-oł-xo y-ičā-si $\quad$ (zow-s(i)). this girl.II.ABS cow. III.ABS. III-lift-POT-XO II-being be-PST.EVID ('This girl was in the state of being able to lift a cow.')

The structural analysis of Tsez we present in section 4 will account for this restriction. To account for the variation in Lak, however, we will need to resort to semantic and/or pragmatic considerations; we bring up those considerations in section 6 . 


\subsubsection{A'-extraction}

Lak and Tsez biabsolutives also differ in terms of $A^{\prime}$-extraction. ${ }^{16}$ In describing this difference, we will rely on three established syntactic properties of ND languages: (i) the clause-bound nature of A'-movement; (ii) the ability of core arguments to undergo A'movement, leaving a gap at the extraction site; (iii) the acceptability of in-situ topicalization marked by topic particles.

(i) Clause-boundedness of A'-movement. In both Lak and Tsez, A' operations are clausebound: long-distance wh-questions and long-distance scrambling are disallowed, as shown for Lak in (36) and (37); see Polinsky \& Potsdam (2001: 603) for Tsez.

a. Nit:i-n k'ul-s:a-r-iw,

Lak

mother-DAT know-ASSRT-PRS-Q

Rasul ci d-ullaj-s:a-r-iw?

Rasul.ABS.I what.IV.ABS IV-build-ASSRT-PRS-Q

'Does mother know what Rasul is building?'

b. ${ }^{*} \mathrm{Ci}_{\mathrm{i}} \quad$ nit:i-n k'ul-s:a-r-iw, $\quad$ Rasul $t_{\mathrm{i}}$ what.IV.ABS mother-DAT know-ASSRT-PRS-Q Rasul.I.ABS

d-ullaj-s:a-r-iw?

IV-build-ASSRT-PRS-Q

${ }^{16}$ Rudnev (2012) argues that what is traditionally identified as A'-movement is actually A-movement in Avar (we are grateful to an anonymous reviewer for pointing out this work to us). Reconstruction and binding facts indicate that the relevant constructions in Lak and Tsez are instances of A'-movement (see Polinsky \& Potsdam 2001, 2002 for Tsez). Whether or not ND languages show parametric variation in the syntax of whquestions, relativization, topicalization, and focusing may call for further study, but this question does not affect our discussion. 
('Does mother know what Rasul is building?')

a. Rasul-lu-1 buwsunni, [Ali-1 dušn-in t'ut'iw d-ullušiwu]. Rasul-OS-ERG said Ali-ERG girl-DAT flower.IV.PL.ABS IV-gave 'Rasul said that Ali gave flowers to the girl.'

b. *Dušn-in ${ }_{\mathrm{i}}$ Rasul-lu-1 buwsunni, [Ali-1 $t_{\mathrm{i}} \quad$ t'ut'iw girl-DAT Rasul-OS-ERG said Ali-ERG flower.IV.PL.ABS d-ullušiwu]. IV-gave ('Rasul said that, to the girl, Ali gave flowers.')

c. *T'ut'iwi $\quad$ Rasul-lu-1 buwsunni, [Ali-1 dušn-in $t_{\mathrm{i}}$ flower.IV.PL.ABS Rasul-OS-ERG said Ali-ERG girl-DAT d-ullušiwu]. IV-gave ('Rasul said that flowers, Ali gave to the girl.')

(ii) Relativization with a gap. Lak and Tsez allow relativization with a gap in all argument positions (see Polinsky et al. 2012 for Avar, Comrie \& Polinsky 1999a, 1999b, Polinsky \& Potsdam 2001 for Tsez; Kazenin 2013 for Lak).

a. Žek'-āa bišwa r-ac-no. Tsez man-ERG food.IV.ABS IV-eat-PST.NONEVID

'The man ate the food.' 


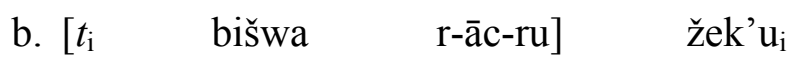

$$
\text { food.IV.ABS IV-eat-PTCP man.ABS }
$$

'the man that ate the food'

c. [žek'-ā $\left.\quad t_{\mathrm{i}} \quad \mathrm{r}-\overline{\mathrm{a}} \mathrm{c}-\mathrm{ru}\right] \quad$ bišwa

man-ERG IV-eat-PTCP food.ABS

'the food that the man ate'

(iii) Marking of information-structural categories. Several ND languages have dedicated topic particles which mark an A'-topic in situ. This property is discussed in detail for Tsez in Polinsky \& Potsdam (2001: 593-597), who show that the topic particles -no and -gon (illustrated in (39)) are subject to island constraints (see also Imnajšvili 1963: 265, 272-273 on the meaning of these particles). As (39) shows, XPs marked with these particles can co-occur in the same utterance.
a. Už-ā-gon
keč’
qaxix.
Tsez

boy-ERG-TOP.CONTR song.III.ABS sing.PRS

'As for the boy, he is singing a song.'

b. Už-ā keč'-gon qaגix.

boy-ERG song.III.ABS.TOP.CONTR sing.PRS

'As for the song, the boy is singing it.'

c. Už-ā-n yedu keč'-gon qaxix.

boy-ERG-TOP this song.III.ABS.TOP.CONTR sing.PRS

'The boy, this song, is singing.' 
Lak does not have a topic particle, making it impossible for us to compare the two languages with respect to this property. ${ }^{17}$

With these three properties in mind, let us consider the possibilities for $\mathrm{A}^{\prime}$-extraction out of biabsolutive constructions in Lak and Tsez. In Lak, A'-extraction works the same way in ergative, dative, and biabsolutive constructions: both core arguments (agent/experiencer and theme) can be scrambled, wh-questioned (with fronting of the whword), relativized, and topicalized. The word order in Lak biabsolutives is relatively free; in particular, the theme argument can scramble to a clause-initial position, as in (40)a, or appear to the right of the verb, as in (40)b.
a. ?Q:at:a
A ${ }^{\complement}$ li $\quad t_{\mathrm{i}} \quad$ b-ullaj
$\varnothing$-ur.
Lak
house.III.ABS Ali.I.ABS III-do.PROG I-AUX

'Ali is building the house.'

b. B-ullaj $\quad$ A $^{\complement}$ li $\quad$ q:at:a $\quad \varnothing$-ur.

III-do.PROG Ali.I.ABS house.III.ABS I-AUX

'Ali is building the house.'

Both absolutive DPs in the biabsolutive construction can undergo wh-movement and relativization, as shown in (41) and (42), respectively.

17 Forker (2012: 89) lists Lak among those languages that have "patientfocus/topicalization with particle," but in her table summarizing different properties of ND biabsolutives, gives both "yes" and "no" values for this property in Lak. Neither our own data nor the available descriptions of Lak (Murkelinskij 1971; Kazenin 1998, 2013) include topic particles. 
(41)
a. $\mathrm{Cu}_{\mathrm{i}}$
$t_{i} \quad \mathrm{q}: \mathrm{at}: \mathrm{a}$
b-ullaj $\varnothing$-ur?
Lak

Who.I.ABS house.III.ABS III-do.PROG I-AUX

'Who is building the house?'

b. $\mathrm{Ci}_{1}$

$$
t_{\mathrm{k}} t_{i} \text { b/d-ullaj } \quad \varnothing \text {-ur } \quad \mathrm{A}^{\mathrm{⿷}} \mathrm{li}_{\mathrm{k}} ?
$$

what.ABS

$$
\text { III/IV-do.PROG I-AUX Ali.I.ABS }
$$

'What is Ali building (doing)?'

c. $\mathrm{Ci}_{\mathrm{i}} \quad \mathrm{A}^{\mathrm{q}} \mathrm{li} \quad t_{i}$ b/d-ullaj $\varnothing$-ur?

What.ABS Ali.I.ABS III/IV-do.PROG I-AUX

'What is Ali building?'

(42)

a. Admina lu itabaq'in-t'i-s:a-r.

man.I.ABS book.III.ABS publish-FUT-ASSRT-3

'The man will publish a book.'

b. $\left[\begin{array}{lll}t_{\mathrm{i}} & \text { lu itabaq'in-t'i-s:a }] \text { admina } \\ \mathrm{i} & \text { ad }\end{array}\right.$ book.III.ABS publish-FUT-PTCP man.I.ABS

'the man that will publish a book'

c. [admina $t_{\mathrm{i}}$ itabaq'in-t'i-s:a] $\operatorname{lu}_{\mathrm{i}}$ man.I.ABS publish-FUT-PTCP book.III.ABS

'the book that the man is going to publish'

In contrast to Lak, the biabsolutive construction in Tsez is subject to restrictions on $\mathrm{A}^{\text {' }}$ operations. The theme argument cannot scramble, (43), and cannot undergo wh-fronting, (44); in the ergative construction, however, no such restrictions are found. 
(43)

$\begin{array}{lllll}\text { a. } * \text { Žek'u } & \text { r-ac'-xo bišwa } & \varnothing \text {-ič-asi } & \text { (yoł). }\end{array}$ man.I.ABS IV-eat-XO food.ABS I-stay-RES be.PRS

('The man is still in the state of eating (the) food.')

b. *Žek'u $\quad$ r-ac'-xo $\varnothing$-ič-asi (yoł) bišwa. man.I.ABS IV-eat-XO I-stay-RES be.PRS food.ABS

('The man is still in the state of eating (the) food.')

c. *Bišwa žek’u $\quad$ r-ac'-xo_ $\quad \varnothing$-ič-asi $\quad$ (yoł). food.ABS man.ABS IV-eat-XO I-stay-RES be.PRS

('The man is still in the state of eating (the) food.')

(44)
a. Žek'u šebi
r-ac'-xo $\quad \varnothing$-ič-asi $\quad($ yoł $) ?$

man.I.ABS what.IV.ABS IV-eat-XO I-stay-RES be.PRS

'What is the man engaged in eating?'

b. *Šebi $\quad$ žek'u $\quad t_{\mathrm{i}} \quad$ r-ac'-xo $\quad \varnothing$-ič-asi $\quad$ (yoł)? what.IV.ABS man.I.ABS IV-eat-XO I-stay-RES be.PRS

('What is the man engaged in eating?')

Next, the theme argument in the Tsez biabsolutive construction cannot be relativized at all, (45)c, whereas the agent argument can relativize with a gap at the extraction site (45)b:

$\begin{array}{lllll}\text { a. Žek'u bišwa } & \text { r-ac'-xo } & \varnothing \text {-ič-asi } & \text { (yoł). }\end{array}$ man.I.ABS food.IV.ABS IV-eat-XO I-stay-RES be.PRS 'The man is engaged in eating food.' 


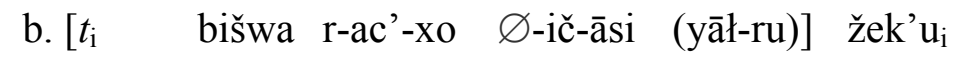

$$
\text { food IV-eat-XO I-stay-RES be-PTCP man }
$$

'the man who is engaged in eating (the) food'

$$
\begin{aligned}
& \text { c. *[žek'u } \left.\quad t_{\mathrm{i}} \quad \text { r-ac'-xo } \quad \varnothing \text {-ič-āsi } \quad(\text { yāł-ru })\right] \quad \text { bišwa } \\
& \text { man.ABS IV-eat-XO I-stay-RES be.PTCP food }
\end{aligned}
$$

('the food that the man is engaged in eating')

Finally, dedicated topic markers cannot appear on the theme in the biabsolutive construction; no such restriction occurs in the ergative construction. The examples below illustrate the relevant contrast—compare (39)a-b above, where either the ergative DP or the absolutive object DP can appear with the contrastive topic marker, and (46)a-b, where only the agent absolutive can be topic-marked. ${ }^{18}$
a. Uži-gon/uži-n
keč
qaxix
$\varnothing$-ičāsi
(yoł). $\quad$ Tsez boy.I.ABS-TOP.CONTR/-TOP song.III.ABS sing.XO I-stay.RES be.PRS

'THE BOY is singing a song.'

b. *Uži keč'-gon/ keč'-no qaגix $\varnothing$-ičāsi (yoł). boy.I.ABS song.III.ABS.TOP.CONTR/-TOP sing.PRS I-stay.RES be.PRS

('The boy is singing A/THE SONG.')

Forker (2012) proposes a discourse-pragmatic explanation for the ungrammaticality of (46)b; she suggests that the agent is the "pragmatic center" of the biabsolutive construction, which presumably rules out the possibility of topicalizing or contrasting the

\footnotetext{
${ }^{18}$ Forker (2012: 88) presents a similar example from Tsez but with the resultative form omitted (as it appears in fragments).
} 
theme. However, an utterance can have more than one "pragmatic center." Above, we presented an example of an ergative utterance that contained both a (regular) topicmarked DP and a contrastive topic-marked DP (39)c. If such co-occurrence is possible in Tsez ergative constructions, why should it be ruled out in the biabsolutive construction?

While a pragmatic explanation may well be relevant for some ND languages, in Tsez, the restriction against topic particles on the lower absolutive is part of a family of A'-constraints (see Polinsky \& Potsdam 2001 for an extensive discussion). In other words, the constraint illustrated in (46)b is consistent with the other restrictions on A'movement of the theme in the Tsez biabsolutive construction. We account for this restriction in section 5 .

\subsubsection{Biabsolutives: Summary}

The biabsolutive differs from the ergative and dative constructions in case, agreement, meaning, and optionality. Concerning these basic facts, Lak and Tsez biabsolutives are superficially similar, but they also differ in a number of significant ways. Critical properties of biabsolutives in the two languages are laid out below. ${ }^{19}$

${ }^{19}$ In addition to the properties listed in Table 3 , in her survey of the biabsolutive construction across ND, Forker (2012) mentions the alternation of the biabsolutive with the affective construction, which we will discuss in sections 5 and 7.1, and "agent focusing". 
Table 3. Biabsolutive constructions in Lak and Tsez: Main properties

\begin{tabular}{|l|c|c|}
\hline & Lak & Tsez \\
\hline Two ABS-marked DPs & $\checkmark$ & $\checkmark$ \\
\hline Lexical verb agrees with Theme (lower ABS) & $\checkmark$ & $\checkmark$ \\
\hline Auxiliary agrees with Agent (higher ABS) & $\checkmark$ & $\checkmark$ \\
\hline Imperfective interpretation & $\checkmark$ & $\checkmark$ \\
\hline Synthetic verb form as predicate & $\checkmark$ & $*$ \\
\hline Theme scrambling & $\checkmark$ & $*$ \\
\hline Wh-fronting of theme & $\checkmark$ & $*$ \\
\hline Theme relativization & $\checkmark$ & $*$ \\
\hline Theme topicalizaton in situ & $\checkmark$ & $*$ \\
\hline Affective and potential predicates possible & & $*$ \\
\hline
\end{tabular}

While Lak and Tsez show surface similarities in the biabsolutive construction, constraints on scrambling and $\mathrm{A}^{\prime}$-movement suggest that the construction merits distinct analyses in the two languages. Before we can delve into the derivation of the biabsolutive, however, we first need to establish how case and agreement are licensed in these two languages.

\section{Case and agreement licensing in Lak and Tsez}

In this section, we present a description and analysis of the licensing of the ergative, absolutive, and dative cases, and outline the syntax of agreement in the two languages we are examining. 


\subsection{Case licensing}

\subsubsection{Basic assumptions and structures}

Our case-licensing proposal relies on several analytical ingredients. First, we assume the presence of functional heads, which bear agreement features and are responsible for licensing case. Both Tsez and Lak have auxiliary verbs such as 'do' and 'be'/'stay'. We assume, uncontroversially, that auxiliaries, like lexical verbs, head their own projections (Cinque 2004; Bošković 2007; 2014, a.o.).

Our next assumption is that the absolutive case is structural, whereas the ergative and the dative are inherent cases licensed by different kinds of $v$; the basis for this assumption is that the heads licensing dative and ergative case have specific semantics, while the absolutive is checked structurally (cf. Aldridge 2004, 2008; Legate 2008; Woolford 2006, a.o). In at least some languages, there is reason to identify two possible licensing heads for the absolutive: the $v$ head, which licenses the absolutive object, and the inflectional head, which licenses the absolutive subject (cf. Aldrige 2004; 2008; Legate 2008). In Lak and Tsez, however, absolutive subjects and absolutive objects can be licensed equally low, inside the $\nu \mathrm{P}$, as we will show presently.

The evidence for case licensing comes from deverbal nouns in Lak and Tsez. Deverbal nouns or nominalizations are typically referred to as masdars in the literature on ND languages; we adopt this terminology below. 
Following the Distributed Morphology framework (cf. Halle \& Marantz 1993), deverbal nouns can be formed from a $v$ P base (e.g., Alexiadou 2009, Harley 2009), as shown schematically in (47).

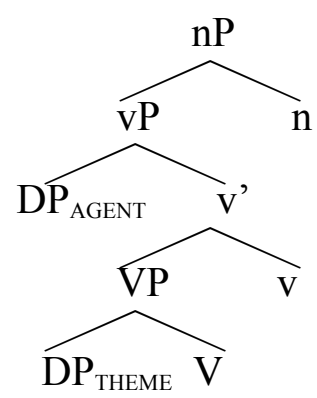

Lak has two types of masdars: the first type is formed with a suffix /-awu/, while the latter type is marked with /-šiwu/. These two masdars are characterized by different morphosyntactic properties, a detailed discussion of which goes beyond the scope of this paper. For our purposes, it is relevant that masdars ending in /-awu/ can express only Aktionsart meaning, whereas /-šiwu/ masdars express aspect, tense and mood (El'darova 1995, Magomedova 2008). ${ }^{20}$ Based on this, we assume that Lak /-awu/ masdars are $v \mathrm{P}$ nominalizations.

Tsez also has two types of masdars: IP-nominalizations in /-ti/ (which appear as complement clauses, marked for aspect and mood—see Polinsky \& Potsdam 2001), and low nominalizations in $/-$ ani/, which are formed from the verb stem and cannot mark aspect, tense or mood. These latter masdars cannot combine with temporal adverbs and only co-occur with manner adverbs.

20 An anonymous reviewer points out that Lak masdars can combine with negation, which is shown in (53)b; since it is traditionally assumed that negation is located between $\nu \mathrm{P}$ and $\mathrm{TP}$, this property of /-awu/ masdars is not inconsistent with our proposal and does not have a bearing on the analysis presented here. 
Thus, both languages offer low nominalizations (masdars), and it is these small-size structures that we will explore with respect to case marking.

Assuming the derivation in (47), if both absolutive and ergative arguments are generated in the $\mathrm{vP}$, we expect case in masdars to be the same as in clauses with finite verbs. This is confirmed for both languages. In Lak intransitive masdars, as in finite contexts, arguments are marked with the absolutive case; this observation holds for masdars based on both (arguably) unaccusative verbs (48) and unergative verbs (49).

a. duš b-uč'-awu

$L a k$

girl.III.ABS III-come-MSDR

'the girl's arrival'

b. šin d-uč'-awu

year.IV.ABS IV-come-MSDR

'coming of the year' (Magomedova 2008: 48)

(49)

duš qaq-awu

girl.III.ABS III.laugh-MSDR

'girl's laughing'

Similarly, in Tsez, both unaccusative and unergative masdars retain the absolutive DP:

xeli b-ex-ani

Tsez

lamb.III.ABS III-die-MSDR

'the lamb's death' (lit.: lamb dying)

$(51)$

onoču $\quad \mathrm{q}^{\text {, }{ }_{\mathrm{w}_{\mathrm{G}}} \mathrm{a} \mathrm{q}} \mathrm{q}^{\mathrm{w} \mathrm{w}_{\text {-ani }}}$

Tsez

hen.III.ABS cluck-MSDR

'the hen's clucking' (lit.: hen clucking) 
The absolutive is therefore licensed uniformly low, inside the $v \mathrm{P}$.

Next, Lak and Tsez masdars provide evidence that the ergative and dative cases are licensed in the specifier of $v \mathrm{P}$. These masdars preserve the case pattern of two-place predicates: ergative-absolutive (52) or dative-absolutive (53) in Lak, and ergativeabsolutive in Tsez, (54):
a. A $^{\complement}$ rab-n-a

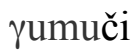
lawsSs:ar.
Lak

Arab-OS-ERG Kumukh.ABS.III III. take.PST

'Arabs conquered Kumukh.'

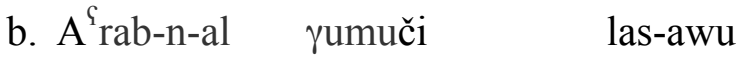

Arab-OS-ERG Kumukh.ABS.III III. take-MSDR

'the conquest of Kumukh by the Arabs' (Kazenin 2013: 27)

(53)

a. A A $^{\mathrm{li}-\mathrm{n} \text { ninu-p:u qama q:a-bitaj. }}{ }^{21}$

Ali-DAT mother-father.ABS memory NEG-leave.PRS

'Ali does not forget his parents.'

b. A A $^{1 i-n}$ ninu-p:u qama q:a-bit-awu

Ali-DAT mother-father.ABS memory NEG-leave-MSDR

'Ali's not forgetting his parents'

(54)

$\begin{array}{llll}\text { a. už-ā keč } & \text { es-no }\end{array}$

boy-ERG poem.III.ABS speak-PST.NONEVID

'The boy read a poem.'

${ }^{21}$ The Lak verb qama bitan 'forget' consists of two elements, the verb bitan 'to leave', and a second element, qama, which is found only in this particular combination (Khaidakov 1962: 282). 
b. už-ā keč ' es-ani

boy-ERG poem.III.ABS speak-MSDR

'the boy's reading of a poem'

All these data converge on the generalization that ergative and dative are inherent cases licensed in spec, $v \mathrm{P}$, whereas absolutive arguments are licensed inside the $v \mathrm{P}$.

\subsubsection{Case checking: Derivation Summary}

The first DP merged in any Lak or Tsez derivation invariably gets absolutive case from $v$. This is illustrated in (55).

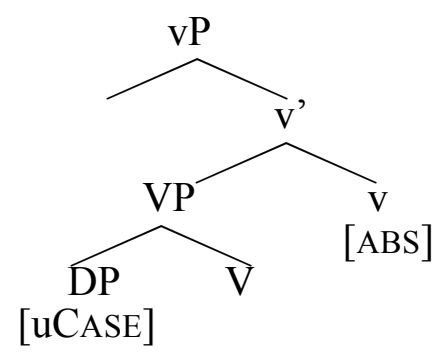

If the verb involved in this nascent absolutive construction is unergative, then the sole argument is merged in the specifier of $v \mathrm{P}$, as shown in (56). At this point in the derivation, only the $v$ head can value [uCASE] on DP, since no other potential casefeature-valuing heads have yet been merged. Thus, the unergative argument gets absolutive case from $v$. This captures the uniform case assignment on intransitives mentioned in section 2 and illustrated by the masdar data in section 3.1.1.

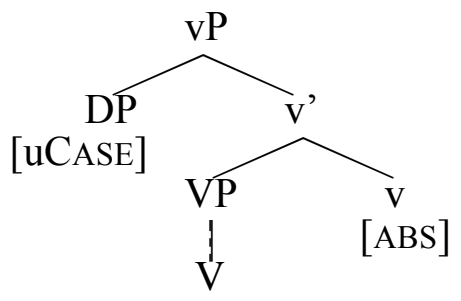


In the ergative construction or a construction with a fear-type psych-verb, the first part of the derivation proceeds as in (55). Next, a second argument is merged in the specifier of $\nu \mathrm{P}$, as shown in (57). We propose that $v$ licenses inherent cases in transitive clauses. The crucial assumption here is that $v$ has an [ERG]/[DAT] case feature only when it also has [TRANSITIVE] and [AGENT]/[PATIENT] features (cf. Wurmbrand 2013). We illustrate this case-licensing pattern for the ergative-absolutive structure below (the dative-absolutive structure is derived similarly $)^{22}$ :

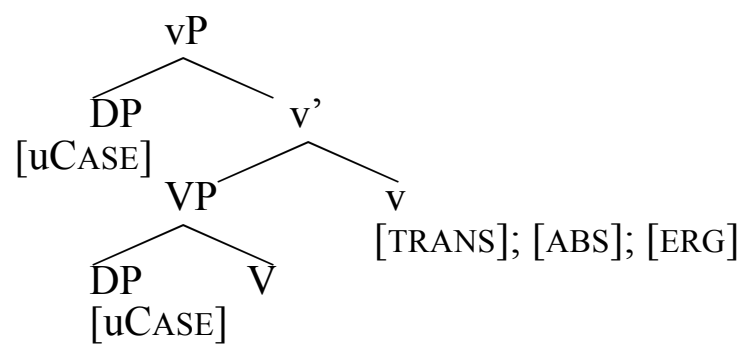

\subsection{Noun class agreement}

Noun class agreement is always determined by an absolutive argument, and the agreement exponent always appears on both lexical and auxiliary verbs, as in (58)-(59).

A ${ }^{\complement}$ li-1 anawarnu k’iwa zadača b-uwunni. Lak

Ali-ERG fast two problem.III.ABS III-solved

'Ali quickly solved two problems.'
A 1 li-1
q:us-u- $\chi$
p:irinž
kanaj b-ur.

Ali.I-ERG

spoon.IV-OBL-TRANSLATIVE

rice.ABS.III eat.PROG III-AUX

'Ali eats rice with a spoon.'

${ }^{22}$ We assume that the absolutive case gets assigned first. Thus, when the $v$ head gets merged, the theme DP gets its case valued; by the time the higher, external argument is merged, only inherent case features are left. 
To account for the class agreement facts, we suggest that $v$ heads and auxiliary heads, regardless of their position, have unvalued class features, as shown in (60).

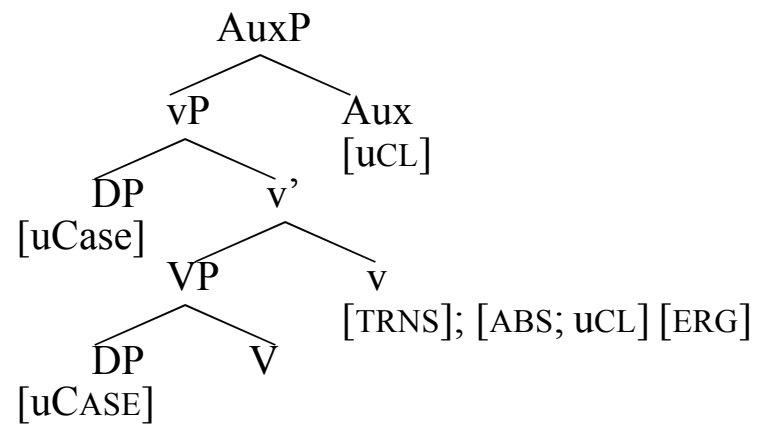

The evidence for $v$ heads as a locus of class agreement again comes from small-size masdars. If $v$ is responsible for class agreement, we should be able to find class agreement exponents in masdars (low nominalizations). This prediction is borne out: masdars with a DP complement in absolutive case show class agreement with this DP, as illustrated in (61).

a. cuppa b-aq'-awu Lak self.III.ABS III-agree-MSDR 'agreement/peace with oneself'

b. curda d-aq'-awu self.II.ABS II-agree-MSDR 'agreement/peace with oneself' (from $a q$ 'in 'be in agreement with someone') (62) 入eli b-ex-ani Tsez lamb.III.ABS III-die-MSDR 'the lamb's death' (lit.: lamb dying) (repeated from (50) above) 
Since neither dative- nor ergative-marked DPs can determine agreement in ND, the only argument available to value $[\mathrm{uCL}]$ on these heads is the absolutive-marked DP. We can account for this restriction by adopting the proposal that languages differ with respect to which arguments are accessible for agreement (Bobaljik 2008, Preminger 2011, 2014). ${ }^{23}$ Bobaljik (2008) proposes an agreement accessibility hierarchy for both nominativeaccusative languages and ergative languages, (63), which states that there are three options made available by $\mathrm{UG}^{24}$ agreement with only the absolutive argument; agreement with absolutive and ergative but not with dative arguments; agreement with all three argument types. ND languages are of the first type, with agreement determined exclusively by absolutive arguments.

$$
\text { DAT }<<\text { ERG }<<\text { ABS }
$$

According to the derivation in (60), the absolutive DP can value the class features on $v$. Class features on the auxiliary verb are valued by the auxiliary probing down within its ccommand domain to retrieve the first fully-valued feature it comes across (cf. Bošković 2007; 2014). To illustrate, consider the following Lak example with two auxiliaries 'be', non-finite and finite:

\footnotetext{
${ }^{23}$ The proposals by Bobaljik and Preminger are similar, but differ with respect to the timing of agreement. Bobaljik (2008) argues that agreement is a post-syntactic operation, whereas Preminger $(2011 ; 2014)$ advocates for agreement in narrow syntax.

${ }^{24}$ The agreement hierarchy for nominative-accusative languages is not relevant to the present discussion.
} 


$$
\text { Rasul-1-ul sual-lu }
$$

b-ullaj-s:a

biwk'un

Lak

Rasul-OS-ERG question.III-PL.ABS III.PL-do.PRGR-PTCP AUX.III.PL.INF

b-ur.

III.PL-AUX.PST

'Rasul was asking questions.'

The structure of this sentence is shown in (65), with irrelevant details omitted:

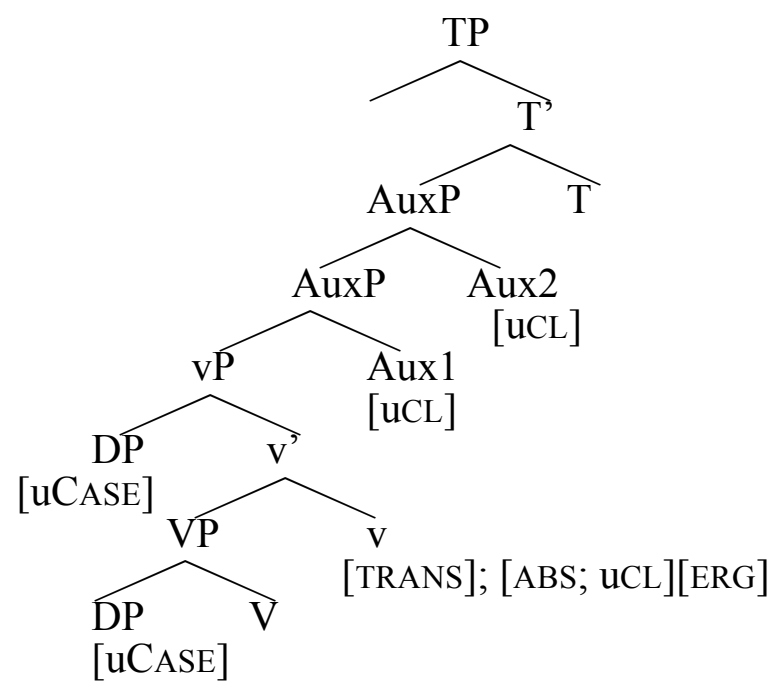

The derivation proceeds as follows. The internal argument ('questions') gets its absolutive case from $v$, and the external argument gets its inherent ergative case from the same functional head. Next, DPABS values [uCL] on $v$. Once the first auxiliary is added, it probes for a DP that can value its $[\mathrm{uCL}]$ features. Upon failing to find such a DP, the auxiliary resorts to agreement with the immediately adjacent head, $v$. Auxiliary 2 also has unvalued class features and lacks a DP to value them. It likewise enters into an agreement relationship with an immediately adjacent head in its c-command domain. 
In this section, we have sketched a brief analysis of the structure of $v \mathrm{P}$ in ND. We contend that the functional head $v$ bears both [uCL] features and case features. Noun class [CL] feature valuation observes locality, in that it can be provided either by an absolutive DP (the original goal) or by an immediately adjacent $v$ head that has valued class features.

\section{The syntax of Lak biabsolutives}

We can now build on the syntactic derivations established in the previous section to analyze the biabsolutive construction in Lak and Tsez.

Recall the differences between Lak and Tsez biabsolutives presented in Table 3 (repeated below). Using constraints on A'-movement as diagnostics, we demonstrated that, while the biabsolutive constructions in Lak and Tsez appear identical on the surface, at their core, these constructions are based on different syntactic structures. Accordingly, we present different analyses for these two constructions in the discussion that follows. In this section, we argue for a restructuring analysis of Lak biabsolutives; in section 5, we present an analysis of Tsez biabsolutives that relies on the presence of a PP complement. 
Table 3. Biabsolutive constructions in Lak and Tsez: Main properties

\begin{tabular}{|l|c|c|}
\hline & Lak & Tsez \\
\hline Two ABS-marked DPs & $\checkmark$ & $\checkmark$ \\
\hline Lexical verb agrees with Theme (lower ABS) & $\checkmark$ & $\checkmark$ \\
\hline Auxiliary agrees with Agent (higher ABS) & $\checkmark$ & $\checkmark$ \\
\hline Imperfective interpretation & $\checkmark$ & $*$ \\
\hline Synthetic verb form as predicate & $\checkmark$ & $*$ \\
\hline Theme scrambling & $\checkmark$ & $*$ \\
\hline Wh-fronting of theme & $\checkmark$ & $*$ \\
\hline Theme relativization & $\checkmark$ & $*$ \\
\hline Theme topicalizaton in situ & $\checkmark$ & $*$ \\
\hline Affective and potential predicates possible & & $\checkmark$ \\
\hline
\end{tabular}

Let us revisit an example of the biabsolutive construction in Lak:

$$
\text { A }{ }^{\mathrm{f}} \text { li } \quad \text { b:at:a } \quad \text {-ullaj } \quad \varnothing \text {-ur. Lak }
$$

Ali.I.ABS house.III.ABS III-do.PROG I-AUX

'Ali is in the state of building a house.' (=(29) above)

Several facts about Lak biabsolutives are relevant for the discussion here. First, biabsolutive constructions always have a progressive or durative reading. Second, the biabsolutive construction is an optional alternative to the ergative construction. Third, biabsolutives are equally possible with synthetic and analytic verb forms. ${ }^{25}$ All these facts, for which we provided evidence in section 3, suggest that Lak biabsolutives involve restructuring. The optionality of restructuring is well known (Wurmbrand 2001; 2004; Cinque 2004, a.o.), and the presence of aspectual heads in restructuring is also crosslinguistically well established (see Fukuda 2008; Takahashi 2012 for a recent discussion).

${ }^{25}$ The example in (66) shows an analytic form; see (41) above, as well as examples throughout the discussion below, for synthetic forms. 
We propose that the functional head $v$ of a Lak biabsolutive is specified for the aspectual feature [progressive]. The special feature [ASP] on this functional head is responsible for the difference in meaning between ergative/dative constructions and biabsolutives. The structure of the biabsolutive construction is that of standard restructuring verbs.

Under restructuring, the matrix verb or the functional head can select a complement of smaller-than-clause size, between VP and TP (Wurmbrand 2001; 2004; Fukuda 2008). We propose that, in Lak, it is a VP that the functional head selects. This VP contains the verb and its complements, but no subject or higher functional heads. The subject in such a structure is never projected; the object $\left(\mathrm{DP}_{1}\right)$ is assigned case by the aspectual head $v$. The subject of the entire clause $\left(\mathrm{DP}_{2}\right)$ is then assigned absolutive case by $\mathrm{T}$.

The proposed structure for the biabsolutive construction in Lak is shown in (67).

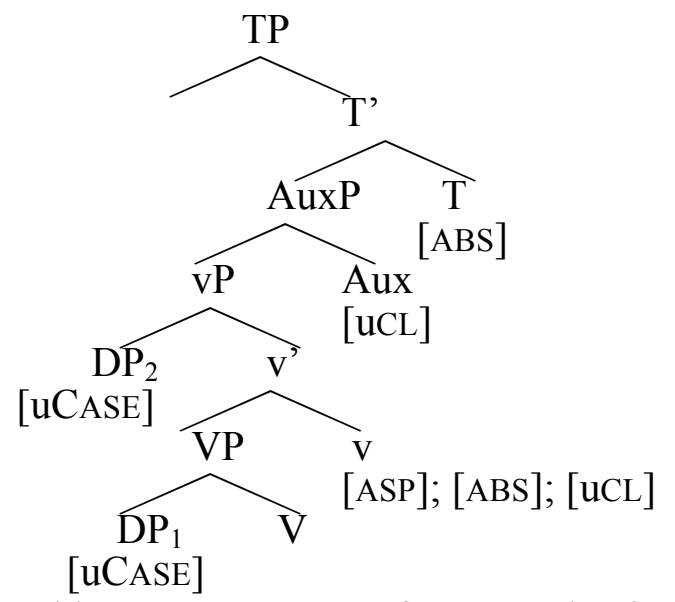

The main evidence for this structure comes from masdar formation and the morphology of aspectual marking. Starting with the masdars, recall that /-awu/ embeds a $v \mathrm{P}$, not a TP. Such masdars can be formed from ergative (68)a or dative constructions, but cannot be formed from the biabsolutive construction (68)b: 
a. A ${ }^{\complement}$ li-1 q:at:a b-ulla-la-wu Lak

Ali-ERG house.III.ABS III-do-PRGR-MSDR

'Ali's building of the house'

b. ${ }^{*}{ }^{\complement} \mathrm{l} l i \quad$ q:at:a $\quad$ b-ulla-la-wu

Ali.ABS house.III.ABS III-do-PRGR-MSDR

The other type of masdars, with the suffix /-šiwu/, embed TPs and can be formed from both constructions, the ergative (69)a and the biabsolutive (69)b; in both instances, the case marking of the finite clause is preserved.

a. ?A ${ }^{\complement}$ li-1 q:at:a b-ullaj b-aq:a-šiwu Lak

Ali-ERG house.III.ABS III-do.PROG III-AUX.NEG-MSDR

'Ali's not building of the house' (='the fact that Ali is not building the house')

b. A ${ }^{\complement}$ li $\quad$ q:at:a $\quad$ b-ullaj $\quad \varnothing$-aq:a-šiwu

AliABS house.III.ABS III-do.PROG I-AUX.NEG-MSDR

The restructuring analysis is also morphologically supported by the structure of synthetic verb forms that appear in the biabsolutive construction. Lak verbs can have aspectual markers inside synthetic forms (El'darova 1995, Kazenin 2013), ${ }^{26}$ thus:

a. Ga na uhlahi-s:a-r.

Lak

3SG.ABS 1SG.I.ABS catch.I.PROG-ASSRT-3SG

'He is catching me.' (Kazenin 2013: 65)

${ }^{26}$ Lak verbs may include aspectual marking in the root: progressive verbs include the infix /la/ followed by a reduplicated root consonant, as in (70)a, while some perfective roots may bear an extra class agreement exponent, which is reanalyzed as an aspectual marker—cf. /w/ in (70)b (El'darova 1995: 90). 
b. *Ga na uwhu-s:a-r

3SG.ABS 1SG.I.ABS catch.I.PRF-ASSRT-3SG

('He has caugth me.')

Since restructuring is always optional, the presence of the progressive does not guarantee that the clause will appear as a biabsolutive - however, in the absence of a progressive verb form, the biabsolutive is impossible. In other words, the presence of progressive aspect on the predicate licenses that predicate to appear in the biabsolutive.

Because the biabsolutive construction is monoclausal, the order of its constituents should not differ from the standard order found in other constructions. This prediction is borne out. Lak biabsolutive constructions, like ergative and dative constructions, do not have restrictions on word order - i.e., both core arguments can undergo scrambling. Compare the ergative construction in (71) and the corresponding biabsolutive in (72):
a. A $A^{\complement} 1 \mathrm{i}-1 \quad$ q:at:a
b-ullaj
b-ur.
Lak
Ali-ERG house.III.ABS III-do.PROG III-AUX
b. A 1 li-l b-ullaj b-ur q:at:a.
c. q:at:a b-ullaj b-ur A A $^{\mathrm{li}}$-1.
d. b-ullaj b-ur q:at:a A A $^{\complement}$ i-l.
e. b-ullaj b-ur A A $^{\complement}$ i-1 q:at:a.

'Ali is building the house.' 
(72)
a. $\mathrm{A}^{\complement} \mathrm{li}$
q:at:a
b-ullaj
$\varnothing$-ur.
Ali.I.ABS house.III.ABS III-do.PROG I-AUX
b. A ${ }^{\complement}$ li b-ullaj b-ur q:at:a.
c. q:at:a b-ullaj b-ur $\mathrm{A}^{\mathrm{f}}$ li.
d. b-ullaj b-ur q:at:a $\mathrm{A}^{\mathrm{\complement}}$ li.
e. b-ullaj b-ur $\quad A^{\complement} l i \quad$ q:at:a.

'Ali is building the house.'

Under the monoclausal analysis, A'-movement in biabsolutives should be no different from $\mathrm{A}^{\prime}$-movement elsewhere. In particular, the theme absolutive should be accessible to $\mathrm{A}^{\prime}$-movement in biabsolutives, just as it is in Lak ergative or dative constructions. Recall that the theme argument in Lak biabsolutives can undergo both whmovement and relativization. Example (41)c is repeated below; for other data, see examples (41)b and (42):

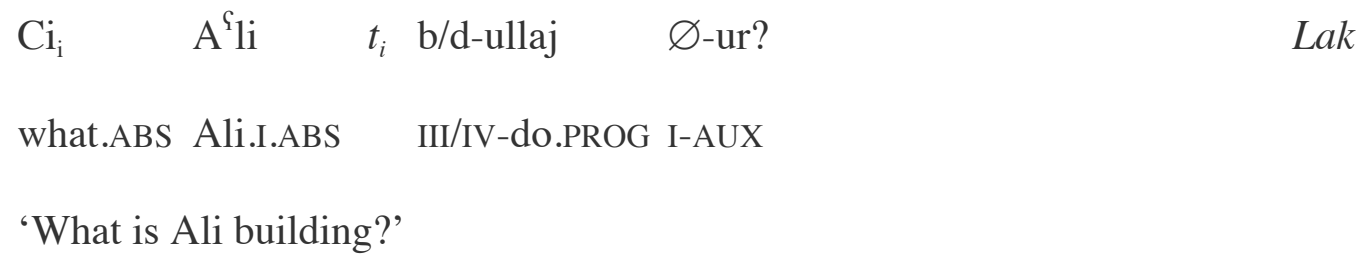

The restructuring analysis of Lak biabsolutives correctly predicts that biabsolutives can have only a single negation, as shown in the examples below.
a. $\mathrm{A}^{\complement} \mathrm{li}$
q:at:a
q:a-b-ullaj
$\varnothing$-ur.
Lak
Ali.ABS house.III.ABS NEG-III-do.PROG I-AUX
'Ali is not building a house.' 

b. ${ }^{*} \mathrm{~A}^{\mathrm{c}} \mathrm{li}$
q:at:a
q:a-b-ullaj
$\varnothing$-aq'ar.
Ali.ABS house.III.ABS NEG-III-do.PROG I-NEG.AUX

Our monoclausal analysis of the biabsolutive construction in Lak is similar to a proposal for Archi biabsolutives put forward by Kibrik (1975), who argues for the monoclausal status of the Archi construction based on the possibility of different word orders. However, a monoclausal analysis of the biabsolutive cannot be directly extended to all other ND languages. In the next section, we will show that the behavior of Tsez biabsolutives calls for a different type of structural analysis.

\section{$5 \quad$ Tsez biabsolutives}

In section 2.2, we showed that Tsez biabsolutives are similar to Lak biabsolutives in that the lexical verb obligatorily agrees with the theme argument, whereas the resultative verb -iča- 'stay' and the auxiliary agree with the absolutive-marked agent. However, unlike Lak, the theme and the lexical verb form an island for $\mathrm{A}^{\prime}$-operations in Tsez, and their order is rigidly fixed. To account for these properties, we propose an analysis in which the predicate of the biabsolutive (-iča- 'stay; be engaged in') takes an absolutive subject and a PP complement, which in turn includes a nominalized verb phrase.

The main components of our analysis are as follows:

(75) a. The theme argument and the lexical verb are embedded under a postpositional head $(-x o)$;

b. The complement of the adposition is a nominalized verb phrase;

c. The PP complement is selected by the light verb-iča- 'stay; be engaged in', 
which appears in the resultative form;

d. The absolutive argument of -iča- 'stay' and the silent argument of the nominalized $v \mathrm{P}$ form a control chain.

\subsection{Theme and lexical verb are inside a PP}

The motivation for (75)a derives from certain facts about the suffix -xo. Consider the following sentence.

$$
\text { Uži t'ek t'et'er-xo } \varnothing \text {-ičā-si (yoł). }
$$

Tsez

boy.I.ABS book.II.ABS read-XO I-stay-RES be.PRS

'The boy is engaged in reading the/a book.'

The lexical verb t'et'ra 'read' is inflected with $-x o$, a suffix that also denotes the imperfective gerund (77)a, the present tense, (77)b, and spatial case.

a. Už-ā t'ek t'et'er-xo yoł/zow-s(i). Tsez boy-ERG book.II.ABS read-GER be.PRS/be-PST.EVID

'The boy is/was reading the/a book.'

b. Už-ā t'ek-mabi t'et'er-xo. boy-ERG book.PL.ABS read-PRS

'The boy reads books.'

It would be reasonable to analyze the biabsolutive form in $-x o$ as an imperfective gerund (cf. for example, Comrie \& Polinsky 2002); indeed, the analysis of this form as a gerund or some other non-finite verbal exponent is somewhat expected, since biabsolutives in other ND languages include participles (compare Kibrik 2001: 394-399 on Bagwali). 
However, gerundial complements in Tsez are generally transparent. Consider the data in (78) for illustration. In (78)a, we observe a transitive gerund in -xo and an auxiliary. In (78)b, the absolutive object of the transitive gerund is questioned with the wh-word scrambled to the left, and in (78)c, the object is relativized. Since Tsez does not allow cross-clausal A'-movement (see Polinsky and Potsdam 2001: 590-591, and section 2.2.2.3), the grammaticality of (78)b,c is evidence that gerundial complements do not induce island effects.

a. Mamalay-ā netintow at'iy qaca r-ayir-xo zow-n(o). Tsez rooster-ERG always wet firewood.IV.ABS IV-bring-GER be-PST.NONEVID 'The rooster always used to bring home wet firewood.' (Cezyas Folklor 2003:44)

b. Šebi $i_{\mathrm{i}} \quad$ mamalay-ā netintow $t_{\mathrm{i}}$ r-ayir-xo zow-ā? what.ABS rooster-ERG always IV-bring-GER be-Q 'What did the rooster always bring?'

c. [mamalay-āa netintow $t_{i} \cdot$ r-ayir-xo yāłi-ru $] \quad$ qaca $_{i}$ rooster-ERG always IV-bring-GER be-PTCP firewood 'the firewood that the rooster always brought'

Thus, if the verb in $-x o$ in the biabsolutive construction were a gerund, the appearance of island effects in this context would be unexpected. If, however, the form is a nominalized $\nu \mathrm{P}$ embedded under an adposition $([\mathrm{PP}[\mathrm{nP}[\mathrm{vP} \ldots]]])$, the extraction facts can be derived straightforwardly. Where does the adposition come from? It belongs to the paradigm of what are typically described as 'spatial cases' (Comrie \& Polinsky 1998). 
Tsez has a large number of spatial expressions, which include two exponents: an element denoting the localization or reference point ('on', 'in', 'at', etc.) and an element denoting motion or absence of motion with respect to that reference point (see Comrie \& Polinsky 1998; Comrie 1999; Kracht 2002). The motion component comes in three types: essive, which denotes the absence of movement, allative, which denotes motion towards the reference point, and ablative, which indicates motion away from some location in space. The structure of Tsez spatial forms is schematized in (79).

$$
\text { NP/DP-Place- } \quad \text { Motion }
$$

\{at, in, under, etc $\}-\{$ essive, allative, ablative $\}$

The form $-x o$ marks the localization 'at', 'by'. When combined with the essive, which has a null exponent, the form $-x o$ is that of the adessive. Consider the following example:

$$
\text { Že } \quad \underline{b^{\top} e \lambda-x o-~} \varnothing \quad \text { zow-s(i). }
$$

Tsez

3SG.I.ABS sheep-AD-ESSIVE be-PST.EVID

'He was a shepherd.' (lit.: he stayed by/at the sheep)

The suffix $-x o$ can also combine with other motion-denoting exponents:

$$
\begin{aligned}
& \text { Ihu-xo-r } \quad \operatorname{pro}_{i} \quad \text { b-āy-nosi } \\
& \text { mamalay- } \bar{a}_{i} \quad q^{\varsigma} a \lambda i-n .
\end{aligned}
$$
stream-AD-LATIVE III-come-CONVERB rooster-ERG shout-PST.NONEVID 'Having come to the stream (lit.: to at the stream), the rooster shouted...' Based on the evidence presented above, we conclude that the suffix $-x o$ in the biabsolutive construction is a localization marker. Spatial forms in ND have been argued to be adpositional phrases (Radkevich 2010). The idea of local cases serving as 
adpositions is not novel; Asbury (2008), Spencer (2008), Trommer (2008), Radkevich (2010), among others, propose that local cases are realizations of P heads.

Support for the interpretation of $-x o$ as a $\mathrm{P}$ head comes from a series of rather subtle extraction facts. In general, the difference between indirect cases and adpositions in Tsez is not easy to discern. Several complications arise. First, Tsez relativization is quite free, and there are no constraints against relativizing out of (oblique) case-marked NPs, e.g. the instrumental case. In contrast, clearly postpositional phrases seem to be islands, as the following example indicates:
a. $\check{Z} \mathrm{e}$

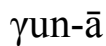
teł $\varnothing$-uq'el-si.
Tsez

he.I.ABS birch.tree-INESSIVE inside I-hide-PST.EVID

'He hid inside a birch tree.'

b. *[že $\quad t_{\mathrm{i}}$ teł $\varnothing$-uq'āti-ru $] \quad \gamma u n_{i}$

he.I.ABS inside I-hide-PTCP birch.tree

('the birch tree inside which he hid')

The problem is that tet is omissible, and therefore (82)b without tet is acceptable although, of course, the specific meaning 'inside which' (as opposed to 'where') is lost. A second complication is that many postpositions double as adverbs, in which case they give at least the appearance of being stranded (see Comrie \& Polinsky 1999a: 86-87 for some discussion).

Sub-scrambling provides a more reliable test of the distinction between indirect case forms and PPs. The descriptive generalization is as follows:

Sub-scrambling in Tsez 
Prenominal modifiers can optionally scramble to the left of their head noun

For example, a possessive expression can scramble to the left of its host, although such sub-scrambling is dispreferred:

a. Somoy-ā [pat'i-s $\quad \gamma^{\text {'wway }}$ žek'-si. Tsez donkey-ERG Fatima-GEN1 dog.ABS hit-PST.EVID

b. ?Pat'i-s Somoy-ā $\quad \gamma^{\uparrow}$ way žek'-si.

Fatima-GEN1 donkey-ERG dog.ABS hit-PST.EVID

'The donkey hit Fatima's dog.'
a. Sal-āa $[$ nesiz qizanyo-r $] \quad \gamma^{\varsigma} u t k u \quad$ roy-s(i).

Ali-erg his.GEN2 family-DAT house.ABS do-PST.EVID

b. ?Nesiz $\quad$ Sal-ā qizanyo-r $\gamma^{\varsigma}$ utku roy-s(i).

his.GEN2 Ali-ERG family-DAT house.ABS do-PST.EVID

'Ali built a house for his family.'

No sub-scrambling is possible out of spatial expressions, including those ending in $-x o$, (87). The contrast between (84)b and (85)b, on the one hand, and (86)b and (87)b, on the other, supports the notion that spatial expressions are indeed PPs, in contrast to the case forms illustrated in (84) and (85).
a. Sali
[pat'i-z
$\gamma^{\complement}$ utka-1-āy]
axi-s.
Tsez

Ali.ABS Fatima-GEN2 house-CONT-ABL speak-PST.EVID

'Ali spoke about Fatima's house.'
b. *Pat'i-z
Sali $\quad \gamma^{\mathrm{u} u t k a-1-\bar{y} y}$
axi-s.
Fatima-GEN2 Ali.ABS house-CONT-ABL
speak-PST.EVID 
a. Ziya uži-z bo $\lambda^{\prime}$-xo kec-no.

cow.ABS boy-GEN2 barn-AD.ESS sleep-PST.NONEVID

'The cow must have slept by the boy's barn.'

b. *Uži-z ziya bo $\lambda$ '-xo kec-no.

boy-GEN2 cow.ABS barn-AD.ESS sleep-PST.NONEVID

\subsection{The adposition -xo selects a nominalized $v P$}

We are now ready to turn to the second component of our analysis, (75)b. Assuming that $-x o$ functions as an exponent of the adessive case in the biabsolutive, it must be attached to some nominal element (NP/DP). We propose that, in the case of Tsez biabsolutives, we are dealing with a verb nominalization. The theme argument and the lexical verb have the following structure in the biabsolutive context:

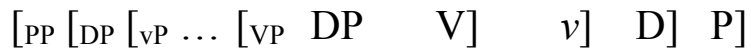

$$
\begin{aligned}
& \text { t'ek t'et'r- } \varnothing \varnothing x o \\
& \text { book read at }
\end{aligned}
$$

In contrast to root clauses, embedded $v$ Ps and VPs in Tsez are strictly verb-final (see section 2.1.1, which explains why the order of the lower absolutive and the verb form in $-x o$ is always fixed). Intervening material can be inserted between the theme and the verb, but neither constituent can scramble to the left or right.

In addition to the spatial head $-x o$, Tsez has a number of other locative forms that can combine with verbal stems. Such combinations yield a rich set of converbs that are used in adjunct clauses (some verbal forms combine directly, as in (89)a, whereas others require an oblique stem-linker, as in (89)b; the morphological conditions on this contrast 
are not yet clear). These forms presumably have a silent D head corresponding to the event argument. For example,

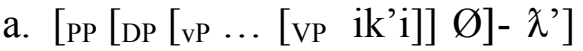
Tsez

$$
\text { go- } \quad \text { SUPER.ESSIVE }
$$

'at the moment of going'

b. [PP [DP [vP … [vP ik'i-zā]] Ø]-q]

$$
\text { go- OS- POST.ESSIVE }
$$

'because of going' (Comrie et al. 1998: 13)

The presence of such forms constitutes additional evidence for the availability of derivations where verbal stems combine with locative affixes. ${ }^{27}$

\subsection{The verb 'stay; be engaged in' takes a PP complement}

Let us now turn to (75)c: the PP is a complement of the verb-iča- 'to stay; be engaged in'. Recall that this verb, in its participial form, is obligatory in Tsez biabsolutives (although it can be dropped in fragments). What is important for us is that the verb -ičais also found outside the biabsolutive, where it takes a PP complement, as shown in (90).

a. $q^{\mathrm{s} u r i-\lambda}-\varnothing \quad \varnothing$-ič-a

Tsez chair-SUPER-ESSIVE I-Stay-INF

'stay (sit) on a chair' (Khalilov 1999)

\footnotetext{
${ }^{27} \mathrm{We}$ are grateful to an anonymous reviewer for pointing out this argument to us.
} 

b. ${ }^{\complement} \mathrm{a} \lambda-\overline{\mathrm{a}}-\varnothing$
$\varnothing$-ǐč-a
village-IN-ESSIVE I-stay-INF
'live in a village'
c. gara-1- $\varnothing$
$\varnothing-i \check{c}-\mathrm{a}$
queue-CONT-ESSIVE I-stay-INF
'stand in line'

As these examples indicate, $-i \check{c} a$ - co-occurs with a number of spatial forms, most of which are essives from one of the seven localization series observed in Tsez. The cooccurrence of $-i \check{c} a$ - with the adessive $-x o$ is just a particular instantiation of this pattern.

\subsection{Control analysis}

We contend that the absolutive argument of $-i \check{c} a$ - and the subject of the nominalized $v \mathrm{P}$ embedded under the postposition $-x o$ are in a control relationship, as schematized in (91) below. Thus, the subject of $-i c ̌ a-$ is thematic and is bound by selectional restrictions. ${ }^{28}$ Recall that one of the meanings of this verb is 'to be engaged in'; this is the meaning that best fits the interpretation of control structures.

$$
\left[{ } _ { \mathrm { vP } } \text { Subject } _ { \mathrm { i } } \left[\mathrm{vp} i \check{c} a\left[\mathrm{pP}\left[\mathrm{DP}\left[\mathrm{vP} \ldots\left[\begin{array}{lll}
\mathrm{vP} & \mathrm{PRO}_{\mathrm{i}} & \ldots . .
\end{array}\right]\right]\right]\right]\right.\right.
$$

The control component of our analysis is confirmed by the fact that inanimate subjects are impossible in Tsez biabsolutives (we adopt the \# symbol to identify the interpretive nature of selectional restrictions):

\footnotetext{
${ }^{28}$ This verb is also used as a control verb, with the meaning of continuation; in that case, it selects an infinitival complement (see Polinsky \& Potsdam 2002). This usage is irrelevant to the discussion here.
} 
\#Buq

yot.

Tsez

sun.III.ABS water.IV.ABS hot IV-make-XO III-stay-RES be.PRS

('The sun is in the state of warming up (the) water.')

\#Laci

aso $\chi$

r-iq-ir-xo

r-ičāsi yoł.

wind.IV.ABS weather.IV.ABS IV-be foggy-CAUS-XO IV-staying be.PRS

("The wind is in the state of ruining the weather.")

The control structure in Tsez biabsolutives accounts for the restriction against inanimate subjects. A similar restriction is also observed in other languages (Forker 2012), but it remains to be seen if the explanation proposed here can apply beyond Tsez. As we discuss in section 6, it cannot apply to Lak.

Given the selectional restrictions that standardly apply to control clauses, it is to be expected that non-volitional animate subjects should be either impossible or marginal in the biabsolutive construction - just as they are in the marginal English example below:

(94) \#Jeremy is engaged in enjoying the Goldberg Variations.

This expectation is met. As we demonstrated in our initial presentation of the biabsolutives, Tsez predicates with experiencer and potential subjects cannot appear in the biabsolutive construction (compare (34) and (35) above). Further support for the relevance of selectional restrictions comes from the Tsez verb -eta, which appears in (95)-(96) below. This verb is ambiguous between three readings: 'like', 'know', and 'want'. Only the 'want' interpretation is consistent with the notion of active agentivity and volitional subjects, and it is this reading alone that is allowed in the biabsolutive construction. Compare: 
(95)

$\begin{array}{lll}\text { a. Kid-ber xabar b-eti-x. Tsez } & \end{array}$ girl-DAT story.ABS.III III-know-PRS

'The girl knows the story.'

b. \#Kid xabar b-eti-x y-ičā-si yoł.

girl.ABS story.ABS.III III-know-XO II-stay-RES be.PRES

("The girl is knowing the story.")

(96)

a. Kid-ber marožni r-eti-x.

girl-DAT ice-cream.ABS.IV IV-like/want-PRS

'The girl likes/wants ice-cream.'

b. Kid marožni r-eti-x y-ičāsi yoł.

girl.ABS ice-cream.ABS.IV IV-like-XO II-stay-RES be.PRS

'The girl wants/\#likes ice-cream.' (cf. 'The girl is wanting ice-cream.')

Thus, as long as the selectional restrictions on volitional animate subjects are met, such subjects can appear in the biabsolutive construction; these facts illustrate that the restriction on verbs with non-ergative subjects is more nuanced than it may seem at first glance.

\subsection{The structure of Tsez biabsolutives}

Based on the discussion above, we arrive at the following structure for the biabsolutive construction in Tsez (irrelevant details not shown). 
(97)

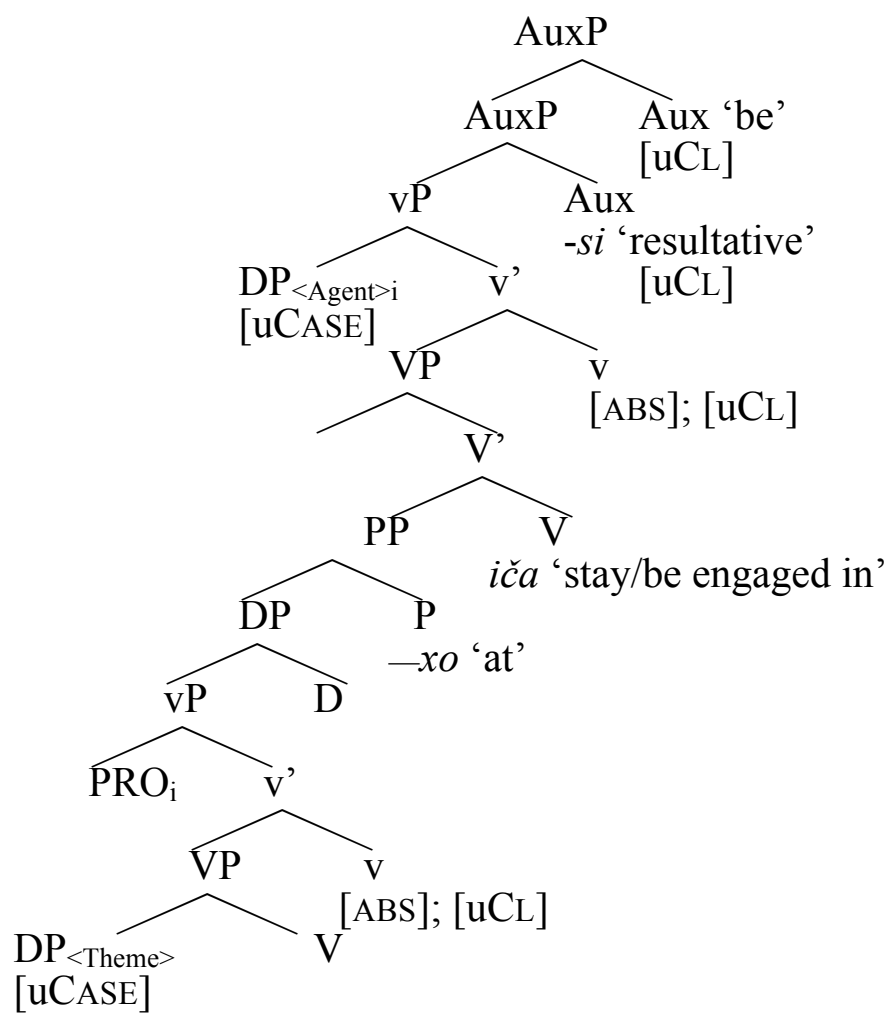

The derivation proceeds as follows. The internal argument $\left(\mathrm{DP}_{<\mathrm{Theme}}>\right)$ is merged inside VP and gets its case valued by the $v$ head dominating VP, which, in its turn, gets its class feature valued by the theme argument. Next, the $v \mathrm{P}$ undergoes nominalization and turns into a DP. The deverbal DP is a complement of P. The PP, headed by the adposition xo 'at', is selected by the control verb -iča-, which is dominated by a light verb with the general meaning of 'do' (cf. Folli \& Harley 2007). The functional head $v$ has unvalued class features and can license absolutive case. The second argument $\left(\mathrm{DP}_{<\mathrm{Agent}}\right)$ is merged in the specifier of this $v \mathrm{P}$, gets its case from $v$, and values the [uCL] features on the $v$ head. The agent DP forms a control chain with the unpronounced subject of the 
nominalized verb phrase below. The two auxiliaries, the resultative $-s i{ }^{29}$ and the auxiliary 'be', are merged, valuing [uCL] from the $v$ head in their c-command domain. ${ }^{30}$

The imperfective/progressive/durative reading of the Tsez biabsolutive follows from its structure. The verb -iča looks like a typical intransitive verb that selects a PPcomplement and theta-marks its subject. In this, the Tsez construction is similar to the English progressive; compare to an expression like to be engaged [PP in....$^{31}$ Historically, English progressives derive from a prepositional construction with a gerundive object (Denison 1993: 387-392; Jespersen 1909-1940, IV: 168-169, 205):

(98) Kim is at [PRO painting the house].

Relics of this construction still survive in $a$-gerund dialects (Wolfram 1980), as in:

(99) Kim is a-painting the house.

The parallels with Tsez are threefold: (i) the construction is divided into two domains; (ii) the lower structure is the complement of an adposition; (iii) the progressive reading follows from the meaning 'stay/be at something'. Under this analysis, Tsez is different from Lak in that the former does not have an aspectual functional head that imparts the imperfective/progressive reading to the biabsolutive construction.

\footnotetext{
${ }^{29}$ This suffix follows a lengthened stem vowel.

${ }^{30}$ Diana Forker (p.c.) notes that she has found three types of biabsolutive constructions in Hinuq, only one of which includes the $-i \check{c} a-$ form. She suggests that Tsez may have two different biabsolutive constructions: the one analyzed here, and another that is similar to the one found in other languages (including Hinuq) and uses the regular auxiliary. Given the differences in judgments between her data and ours, we leave this question up to future research. Given the freedom of auxiliary omission in ND languages, it is not always possible to tell whether an auxiliary is optional.

${ }^{31}$ The parallels extend beyond English; the Tsez progressive is also similar to progressive forms in a number of other languages (see Bybee et al. 1994; Demirdache \& UrribeEtxebarria 2000; Coon 2013b for cross-linguistic overviews).
} 
To summarize, we have proposed that Tsez biabsolutives include a PP constituent adjoined to the participial form of the verb -iča-; this PP constituent comprises the adessive $\mathrm{P}$ head 'at', a member of the extensive set of local adposition forms, and a nominalized VP complement. The use of spatial forms in biabsolutives is likely to be found outside Tsez as well.

\section{A comparison between the proposed analyses and the analyses in the literature}

\subsection{From Tsez to Basque and Mayan and back to Lak}

The analysis of Tsez put forward in section 5 is very similar to the analysis of the Basque biabsolutive construction proposed by Laka (2006). Basque is basically an ergative language, but in the progressive aspect, it loses its ergative marking and contains two absolutive-marked arguments. Laka (2006) argues that the Basque progressive is formed by an intransitive lexical verb which selects a PP complement (e.g., ari 'be (engaged in)'—just as the Tsez verb-iča-; ibili 'be about', or egon 'be/stay'). This PP complement

contains a PRO, ${ }^{32}$ a theme argument, and the lexical verb. Since the lexical verb selecting the PP complement is intransitive, the apparent agent of the embedded lexical verb is actually the argument of the matrix intransitive, and, as such, it receives absolutive case. The two absolutives are assigned in two separate case-licensing domains, as shown in $(100) b$.

32 Other researchers (Preminger 2009, and further references therein) suggest that the complement of -tze/-te is just a bare VP with no subject at all; the apparent "obligatory control" reading in this complement is achieved through interpretive mechanisms discussed in Wurmbrand 2001, rather than through the presence of PRO. 
(100)

a. Emakume-a ogi-ak ja-ten ari da. Basque woman-DET bread-DET.PL eat-IPFV PROG 3A.is

'The woman is eating (the) breads.' (Laka 2006: 173)

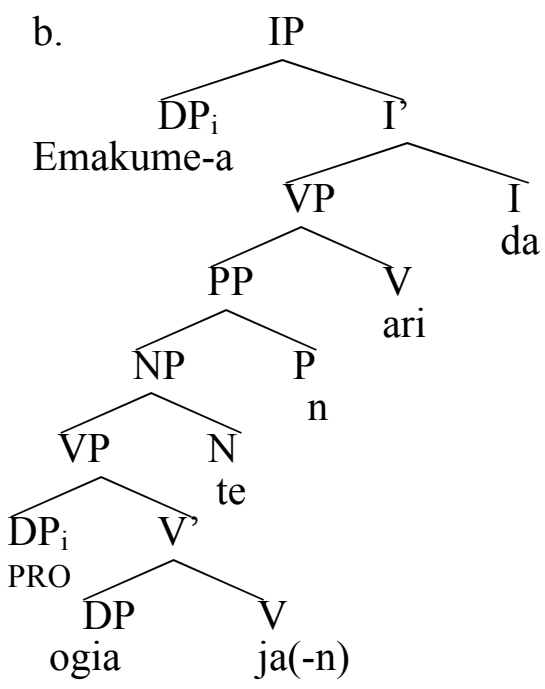

Laka's (2006) analysis of the Basque progressive and our analysis of the Tsez biabsolutive are similar in a number of ways: (i) the lexical verb and theme argument are contained within a PP, selected by the verb 'stay/be'; (ii) the verb phrase is nominalized; (iii) the -te/-tze marker that heads the complement of the locative $-n$ is itself a nominalization marker.

A similar analysis is proposed for Mayan languages by Coon (2010; 2013a). In her analysis, the matrix clause contains a light verb, which takes a DP complement that includes a nominalized verb phrase (no PP is implicated on this analysis). The verb phrase is fully formed before it undergoes nominalization and thus projects its arguments within the nominalized structure. Surprisingly, the Mayan nominalization is not an island for extraction. 
None of the Tsez, Basque, and Mayan analyses permit ergative case marking in the clause. This leads to the appearance of split ergativity (see also Forker 2012: 92 for a connection between biabsolutives and split ergativity). In Basque and Chol (as well as some other Mayan languages), aspect-based split ergativity occurs when progressive/durative predicates form complex clauses, with two separate domains assigning absolutive case. In Tsez, the biabsolutive construction has a monoclausal structure, where two absolutive-marked arguments are assigned in two separate domains (PP and $\nu \mathrm{P}$ ) within the same clause.

It may be tempting to reduce all biabsolutive constructions and, consequently, all instances of aspect-based split ergativity, to complex-clause constructions. However, the data from Lak, for which we proposed a restructuring analysis, sounds a note of caution. A Tsez-style analysis cannot be extended to Lak biabsolutives for the following reasons: (i) Lak theme arguments can undergo A'-movement, which would be unexpected on a Tsez-style analysis, given the island status of PPs and the embedded nominalized complement of the $\mathrm{P}$ head; (ii) Lak lexical verbs in biabsolutives do not bear any morphological reflexes of PPs - i.e., lexical verbs do not have spatial case exponents. Thus, split ergativity may emerge under different circumstances, even in closely related languages.

\subsection{An alternative analysis: Pseudo Noun Incorporation}

In this section, we will discuss an alternative analysis that has been proposed for the biabsolutive construction in ND languages: pseudo noun incorporation (PNI) (see Forker 
2012 for an overview). Although a PNI analysis may hold for some members of this language family, we argue that it is not applicable to either Lak or Tsez.

The essence of the PNI analysis, originally put forward by Massam (2001) for Niuean, is that the theme argument is incorporated into the lexical verb, which alters the clause structure and makes the theme argument inaccessible for case and agreement. In many morphologically ergative languages, absolutive case does not have an overt lexical realization, making it impossible to determine whether an argument lacks case (i.e., has undergone PNI), or is actually zero-marked for the absolutive (see Legate 2008). ${ }^{33}$ Extending the PNI analysis to ND biabsolutives, Forker (2012) claims that the ND theme argument is caseless and forms a unit with the lexical verb, thus making the external argument (agent) the only element eligible to receive absolutive case. Such an analysis would straightforwardly account for case marking (the higher absolutive is the only 'real' case form, while the lower 'absolutive' does not actually bear case) and agreement (the auxiliary verb is intransitive, and therefore agrees with the single absolutive argument). By contrast, the proposals for Lak and Tsez we have presented in this paper do not consider the possibility of the theme argument's agreeing with the lexical verb. There would be two ways to carry out such agreement, depending on the derivational timing. First, agreement may apply after incorporation, in which case the theme argument will be inaccessible for agreement due to its incorporated status. Second, agreement may apply before PNI, in which case the theme argument values [uCL] features on $v$ early in the

${ }^{33}$ However, see Preminger (2011; 2014; McFadden 2014) for arguments that cases like nominative and absolutive are nothing but the absence of case assignment, rendering this distinction moot. 
derivation. Since the relative timing of agreement and incorporation can vary, agreement between the verb and the theme argument cannot be diagnostic of incorporation.

Based on the discussion in Massam $(2001 ; 2009)$, we identify the following aspects of theme arguments that are essential to a PNI analysis:

(101) PNI diagnostics:

a. Durative/progressive/frequentative meaning

b. Productive with an open class of verbs

c. No lexical material should intervene between NP and V, and the order of object and verb must be fixed

d. The incorporated theme is nonspecific/non-referential

e. The incorporated theme is not specified for number

f. The incorporated theme cannot undergo A'-movement

In order to extend Massam's analysis to any ND biabsolutive construction, the theme argument in the relevant language should show the listed properties. Biabsolutive constructions in both Lak and Tsez have durative/progressive meanings and are productive with an open class of verbs, which is consistent with (101)a-b. However, the other predictions made by the PNI analysis are not borne out in either of these languages.

First, the theme and the lexical verb can be split by an adverb, contra (101)c, as illustrated in (102)-(103).
$\mathrm{A}^{\mathrm{\complement}} \mathrm{li}$
(ћurћa) q:at:a
(hurћa) b-ullaj
$\varnothing$-ur.
Lak
Ali.I.ABS slowly house.III.ABS slowly III-do.PROG I-AUX

'Ali is slowly building the house.' 
(103)

Žek'u magalu harihun b-ac'-xo $\varnothing$-ičā-si (yoł). man.I.ABS bread.III.ABS slowly III-eat-XO I-stay-RES be.PRS

'The man is engaged in slowly eating (the) bread.'

In Lak, the theme can also scramble freely and appear both clause-initially and at the right periphery of the clause, as shown in (40) above.

The theme in the biabsolutive construction can be specific and referential, contra (101)d; in particular, it can be expressed by a pronoun, as in (104)-(105).

?Rasul na uhlahi-s:a-r.

Lak

Rasul.I.ABS 1SG.ABS I.catch:DUR-PTCP-3

'Rasul is catching me.'

$\begin{array}{lllll}\text { Eniy } & \text { di/mi/žze } & \text { žek'-xo y-ičā-si } & \text { (yoł). } & T s e z\end{array}$ mother.II.ABS $1 \mathrm{SG} / 2 \mathrm{SG} / 3 \mathrm{SG} . \mathrm{ABS}$ hit-XO II-stay-RES be.PRS

'Mother is engaged in hitting me/you/him/her/it.'

Next, ND biabsolutives are specified for number; we have presented many examples of unambiguously singular objects, and the examples below show definite plurals. Thus, the requirement in (101)e, that pseudo-incorporated objects not be specified for number, is not borne out in Lak and Tsez.

Rasul waj balaj-rdu t'ij $\varnothing$-ur. $\quad L a k$

Rasul.ABS this.PL.ABS song-PL.ABS say.PROG I-AUX

'Rasul is singing these songs.'

\footnotetext{
${ }^{34}$ The class of the pronoun may vary between I or II depending on whether a man or a woman is speaking. Since the verb 'hit' does not show overt agreement, we omit the class on the object pronouns in this example.
} 
$\begin{array}{lllll}\text { kid } & \text { gedo-bi } & \text { r-oy-x(o) } & \text { y-ič-āsi } & \text { zow-s(i) }\end{array}$ girl.II.ABS knit-footwear-PL IIPL-do-XO II-stay-RES be-PST.EVID

'The girl was in the state of making knit footwear.'

Finally, the PNI analysis predicts that theme arguments should not be available for A' operations, (101)f. This prediction is not borne out in Lak (see examples (41)-(42) above). Note that the very fact that themes in Lak biabsolutives can A'-move would lead to problems for the PNI analysis. Verb agreement with the theme would have to take place prior to incorporation, while probing by the auxiliaries would have to occur after incorporation, to prevent the auxiliaries from agreeing with the theme; finally, the theme would have to somehow excorporate to make it eligible for subsequent $\mathrm{A}^{\prime}$-movement.

In Tsez, the prediction in (101)f, that the biabsolutive theme cannot A'-move, holds, but we have been able to account for this fact, as well as the other properties of the Tsez biabsolutive, under the PP analysis. Our solution not only explains the lack of A'movement but also justifies the morphological form of the lexical verb in $-x o$, which we propose contains a postpositional head.

In sum, a PNI analysis of the biabsolutive construction is not feasible for either Lak or Tsez. It remains to be seen whether biabsolutive constructions in other ND languages are amenable to a PNI analysis.

\section{$7 \quad$ Further issues}

In this section, we will briefly take up some issues that follow from the syntactic discussion pursued in this paper. We have postponed discussion of these issues to this 
final section because we do not see them as fully resolved; here, we hope simply to offer some preliminary considerations.

\subsection{The restriction against affective predicates in Lak}

We accounted for the failure of Tsez dative-subject (experiencer-subject) verbs and potential verbs to appear in the biabsolutive construction on syntactic grounds, by appealing to the standard selectional restrictions involved in control structures. The restriction against the use of dative-subject verbs in Lak is less clear; one of our consultants accepts experiencer predicates in the biabsolutive construction, while the others rejected their appearance. The latter pattern, of course, is reminiscent of Tsez. Unfortunately, our account of the Lak syntax does not allow us to appeal to selectional restrictions to explain this discrepancy. However, it is possible to account for the restriction in semantic and pragmatic, rather than syntactic, terms.

Our tentative explanation builds on the observation that biabsolutive constructions in Lak have a well-defined progressive aspect. A number of researchers contend that the semantics of the progressive aspect includes two components: first, it indicates an ongoing event or event-in-progress (EIP), underscored by the construction's cooccurrence with durational adverbials such as 'still'; second, this ongoing event must have come about through the activity of an agentive participant. As we have already mentioned, and as Forker (2012) has documented extensively, inanimate, non-agentive participants are highly dispreferred or even rejected in the biabsolutive. 
Assuming that the biabsolutive necessarily contains these two meaning components, several possible semantic and pragmatic restrictions arise. First, note that the expression of the EIP is actually associated with several kinds of aspect, in particular imperfective and progressive. Progressives are a subset of imperfectives, but not all imperfectives are progressive. Cross-linguistically, imperfective marking is associated with at least three distinct readings (Deo 2009 and references therein):

(108) Readings of the imperfective:

a. the EIP reading

b. the continuous reading with lexically stative predicates

c. the habitual or generic characterizing reading.

In English, the EIP reading (108)a is dominant. The incompatibility of stative verbs with the English progressive, (108)b, has been the subject of much discussion in the literature (Vendler, 1967; Taylor 1977; Vlach 1981; Dowty 1979; Bach 1981; De Swart 1998; Deo 2009). The basic observation is that individual-level predicates (including potential predicates) are infelicitous in the English progressive:

(109) a. \#Kim is knowing mathematics/the answer.

b. ?/\#Sandy was being able to lift $60 \mathrm{lbs}$.

Stage-level statives (e.g., lie, reside, rest) are compatible with progressive marking, but only when the situation denoted by the predicate is potentially subject to change (Dowty 1979). More-or-less permanent situations expressed by individual-level statives or by stage-level statives with immovable subjects are infelicitous in the progressive: 
(110) a. \#New Orleans is lying at the mouth of the Mississippi River. (Dowty 1979: 174)

b. \# Meaning is residing within the text of poems.

We do not take a stand on whether the infelicity of (109) and (110) should be explained under a semantic or a pragmatic account. What matters for us is that progressive aspect either entails or implies temporal contingence for a predicate in its scope. Such temporal contingence is incompatible with the meaning of individual-level predicates and "permanent" uses of stage-level statives. We propose that the use of the progressive in Lak biabsolutives expresses the dynamic quality of the event (its temporal contingency), and therefore blocks the appearance of such verbs as 'know' or 'forget' in the construction. We can test this prediction by examining the use of psych-predicates in the biabsolutive construction. Many dative subjects appear with psych-predicates, which denote permanent or semi-permanent states; such verbs should be in felicitous in a construction that entails temporal contingence, such as the biabsolutive. This prediction is borne out by the infelicity of (111)b below:
a. A $A^{\complement}$ li-n matematika q:a-durčlaj
d-ur.
$L a k$
Ali-DAT math.IV.ABS NEG-understand.PROG IV-AUX
'Ali does not understand math.'

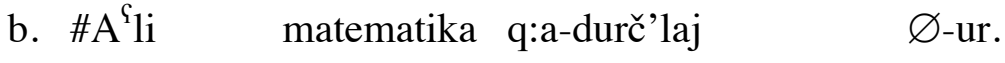
Ali.I.ABS math.IV.ABS NEG-understand.PROG I-AUX
('Ali does not understand math.')

Note, however, that there are speakers of Lak who accept structures like (111)b. We hypothesize that, for such speakers, the aspectual verb no longer limits the interpretation 
of the event to the progressive but, instead, conveys the more general imperfective meaning of which the progressive is a subset. This hypothesis is consistent with the evolution of the progressive construction observed in Indo-European languages (cf. Torres Cacoullos 2012 for Spanish, Deo 2009 for Indo-Aryan, and references therein). Seen in this context, we can understand the Tsez construction as being at a stage of development in which the constraints on its occurrence are fine-grained but still predictable; Lak may represent a later stage in the development of the progressive construction. The fact that Lak speakers have different judgments about this particular construction (some accepting and others rejecting biabsolutives with psych-verbs) may underscore possible ongoing change in its meaning.

Ultimately, the syntactic restrictions observed in the Tsez control structures and the semantic/pragmatic restriction we propose here for Lak may be related, just as the origin of the progressive itself may go back to a control structure (see our discussion in section 5.4). However, it may be more difficult to relate the two sets of restrictions in individual synchronic analyses, which is why we have kept them separate.

\subsection{Learnability}

The data patterns that characterize the biabsolutive construction in Lak and Tsez appear similar in certain respects and exhibit the same characteristic case and agreement patterns, but they also differ in important ways. Tsez biabsolutives exhibit constraints on 
A'-movement and word order that do not apply to Lak. These differences led us to propose distinct analyses for the biabsolutive construction in each language.

Any time we find (nearly) identical surface data with more than one possible underlying structure, we have identified a potential learnability issue. A child who is acquiring Lak or Tsez must determine which biabsolutive-generating structure is active in her language. This problem is compounded by the fact that the factor ultimately distinguishing Lak and Tsez is not observable from the surface features of the biabsolutive. Instead, the analyses we presented for the two languages above hinge on negative evidence. Thus, in order for a learner to arrive at the correct analysis of the biabsolutive construction in her language, she must determine both what is a possible structure and what is not. The learnability problem encountered here is more general than the adoption of the correct biabsolutive structure in two related languages; it arises whenever there is potential structural ambiguity. The case of the biabsolutive construction presents a helpful exemplar for discussing the more general problem of structural ambiguity in first-language acquisition.

\subsubsection{Identifying the biabsolutive in the input}

Before a learner can infer constraints on a structure, he must first learn to identify this structure in the linguistic input. To do so, the learner must be able to track morphological differences between the biabsolutive and the ergative-absolutive construction. In Tsez, this entails keeping track of (a) double absolutive marking, (b) the presence of $-x o$, and 
(c) distinct agreement on -iča- and the lexical verb. However, these characteristics may be obscured by (i) pronominal syncretism in $1^{\text {st }}$ and $2^{\text {nd }}$ person, (112)a; (ii) pro-drop, (112)b; (iii) absence of overt agreement on consonant-initial lexical verbs, (112)c; (iv) homophony in agreement when both absolutive-marked arguments are from the same noun class, (112)d.

(112) Hypothetical biabsolutives

a. Mi di žek'-xo $\varnothing$-ičā-si (yoł).

2SG.ABS/ERG 1SG.ABS hit-XO I-stay-RES be.PRS

'You are engaged in hitting me.'

b. pro magalu b-ac'-xo $\varnothing$-ičā-si (yoł)

pro bread.III.ABS III-eat-XO I-stay-RES be.PRS

'Someone is engaged in eating (the) bread.'

c. Žek'u magalu teł'-xo $\varnothing$-ičǎ-si (yoł).

man.I.ABS bread.III.ABS give-XO I-stay-RES be.PRS

'The man is engaged in giving away (the) bread.'

d. K'et'u magalu b-ac'-xo b-ičā-si (yoł).

cat.III.ABS bread.III.ABS III-eat-XO III-stay-RES be.PRS

'The cat is engaged in eating (the) bread.'

\subsection{Inferring the structure of the biabsolutive}

Learners do more than merely identify strings in the input. They must also determine what structure underlies each given morphological pattern in the language being 
acquired. While in reality the learner must differentiate between the predictions of any $n$ structures that could generate two absolutive arguments, here we concentrate on the learner's task of differentiating between a Lak-like structure and a Tsez-like structure. What ultimately distinguished these constructions for us, the linguists, were the constraints on A'-movement and extraction that were present in Tsez but not in Lak, and some differences in the restrictions on volitional subjects. When linguists determine that a construction isn't possible in a given language, they do so by eliciting acceptability judgments from native speakers. This strategy is not available to the learner. Instead, the learner must make inferences based on strong expectations about what he should see if a given structure is part of his language, and rely on the absence of a particular kind of data to determine that a given structure isn't present. In the Lak-Tsez comparison, the learner would be comparing two hypotheses: $\mathrm{H} 1$, that the biabsolutive construction is an instance of restructuring (as in Lak), and $\mathrm{H} 2$, that the biabsolutive involves a PP complement to a light verb (as in Tsez).

Each of these hypotheses comes with certain expectations about what the linguistic input should look like, if it is responsible for generating the data. That is, the learner would expect that if he were learning a Lak-like language, A'-movement and extraction of the theme from a biabsolutive construction would be possible, and might be encountered at some non-zero rate in the input. Simultaneously, the learner would have to expect that, if he were learning a Tsez-like language, such operations would not be 
generated by the grammar or encountered in the input. ${ }^{35}$ Consequently, if the learner were exposed to Lak input, relatively few instances of biabsolutive constructions containing scrambling, wh-movement, or relativization of the theme would be enough for him/her to infer that the biabsolutive construction in this language is monoclausal. If the learner were instead exposed to the Tsez input, the lack of these operations in biabsolutive constructions would appear suspicious. That is, if the grammar allowed scrambled word orders in a given construction, a learner might expect those word orders to be found at the same rate as scrambled word orders in any other construction. Since this rate is quite high in speech to children, with two word orders often uttered in quick succession (as in (113)), the absence of these orders in the biabsolutive construction should raise a red flag.

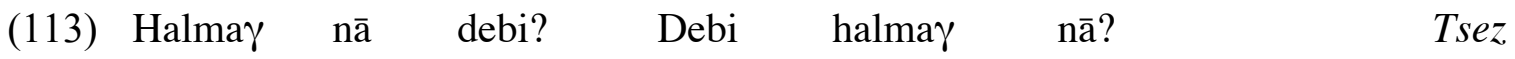
friend.ABS where 2SG.POSS 2SG. POSS friend.ABS where

'Where is your friend? Where is your friend?' (Gagliardi \& Lidz 2014)

Learners have been shown to make use of this kind of suspicious coincidence in wordlearning contexts where they have strong enough expectations about the space of possible word meanings (Xu \& Tenenbaum 2007). It is possible that learners may be able to use the same inferential capacity to determine that the biabsolutive construction in their language is biclausal. At this stage of our knowledge, we are basing these considerations only on production data. Further investigation, including work on comprehension, is needed to test the learnability strategies outlined in this section.

${ }^{35}$ This kind of expectation depends on the learner's knowledge of other components of his grammar, such as the fact that scrambling and wh-movement aren't possible across clause boundaries. 


\section{Conclusions}

In this paper, we have presented and analyzed data from the biabsolutive constructions in two ND languages, Lak and Tsez. Despite many surface similarities between their respective biabsolutives, Lak and Tsez call for different syntactic analyses of this construction. We argued that the biabsolutive construction in Lak is an instance of restructuring, due to the presence of a functional head that has a specified aspectual feature, [progressive]. In this construction, the lower absolutive (the theme) receives case from the aspectual head, whereas the higher absolutive receives its case from $\mathrm{T}$. The construction is clearly monoclausal, as a number of syntactic diagnostics illustrate.

Tsez biabsolutives, on the other hand, have a structure in which the theme and the lexical verb are contained in a PP selected by a light verb, according to our analysis. The proposed structural difference between Lak and Tsez biabsolutives allows us to derive the restrictions on $\mathrm{A}^{\prime}$-movement of the theme argument in Tsez, as this argument is inside a nominalized $v \mathrm{P}$ embedded under a postposition.

We are now in a position to show how the critical properties of Lak and Tsez biabsolutives are accounted for under the two analyses. 
Table 4. Biabsolutive constructions in Lak and Tsez: Main properties

\begin{tabular}{|c|c|c|}
\hline & $\begin{array}{c}\text { Lak: Monoclausal structure } \\
\text { with a restructuring aspectual } \\
\text { verb }\end{array}$ & $\begin{array}{c}\text { Tsez: nominalized verb phrase } \\
\text { embedded under a } \\
\text { postpositional head }\end{array}$ \\
\hline $\begin{array}{l}\text { Two ABS-marked } \\
\text { DPs }\end{array}$ & $\begin{array}{c}\text { Follows from two separate } \\
\text { licensing domains for ABS ( } v \\
\text { and } \mathrm{T})\end{array}$ & $\begin{array}{l}\text { Follows from two separate } \\
\text { licensing domains for ABS } \\
(\text { embedded } v \text { and matrix } v)\end{array}$ \\
\hline $\begin{array}{l}\text { Lexical verb agrees } \\
\text { with Theme (lower } \\
\text { ABS), and auxiliary } \\
\text { agrees with Agent } \\
\text { (higher ABS) }\end{array}$ & $\begin{array}{l}\text { Follows from two separate } \\
\text { agreement domains }\end{array}$ & $\begin{array}{l}\text { Follows from two separate } \\
\text { agreement domains }\end{array}$ \\
\hline Theme scrambling & $\begin{array}{l}\text { Possible: Monoclausal structure } \\
\text { allows scrambling }\end{array}$ & $\begin{array}{l}\text { Impossible: Theme is inside an } \\
\text { island }\end{array}$ \\
\hline $\begin{array}{l}\text { Wh-fronting of } \\
\text { theme }\end{array}$ & $\begin{array}{l}\text { Possible: Wh-question } \\
\text { formation as in all other } \\
\text { monoclausal structures }\end{array}$ & $\begin{array}{l}\text { Impossible: Theme is inside an } \\
\text { island }\end{array}$ \\
\hline Theme relativization & $\begin{array}{l}\text { Possible: Relativization as in } \\
\text { all other monoclausal structures }\end{array}$ & $\begin{array}{l}\text { Impossible: Theme is inside an } \\
\text { island }\end{array}$ \\
\hline $\begin{array}{l}\text { Theme topicalizaton } \\
\text { in situ }\end{array}$ & $\begin{array}{l}\text { Possible: Topicalization as in } \\
\text { all other monoclausal structures }\end{array}$ & $\begin{array}{l}\text { Impossible: Theme is inside an } \\
\text { island }\end{array}$ \\
\hline $\begin{array}{l}\text { Imperfective } \\
\text { interpretation }\end{array}$ & $\begin{array}{l}\text { Determined by the progressive } \\
\text { (imperfective) aspectual head }\end{array}$ & $\begin{array}{c}\text { Compositionally determined by } \\
\text { the combination of the light } \\
\text { verb with a PP }\end{array}$ \\
\hline $\begin{array}{l}\text { Affective and } \\
\text { potential predicates }\end{array}$ & $\begin{array}{l}\text { Ruled out by non-syntactic } \\
\text { constraints on progressive } \\
\text { interpretation }\end{array}$ & $\begin{array}{l}\text { Ruled out by selectional } \\
\text { restrictions imposed by the } \\
\text { control predicate }-i \check{c} a-\end{array}$ \\
\hline
\end{tabular}

Our conclusion, that two related languages have two different underlying structures for an apparently identical construction, has implications for the biabsolutive in ND more generally. Related languages may be classified as "Lak-type" or "Tsez-type" if their facts align with the properties outlined in this paper. Other researchers have suggested that similar analyses are possible; for example, Harris and Campbell (1995: section 7.4.3) discuss two biabsolutive constructions in Avar, suggesting that one is amenable to the analysis proposed here for Lak, while the other may be different from both analyses 
discussed here. Harris and Campbell's discussion suggests that there are other biabsolutive "types" in the family, and we hope that the proposed contrast between Lak and Tsez will inspire other comparative analyses within ND. If our proposals are on the right track, it may also be useful to compare diachronic pathways from one structure to the other: should one expect the development of a monoclausal structure from a biclausal one or vice versa, and what would the trigger for such a development be?

The existence of two underlying structures for one surface pattern also poses a potential learnability issue for a child acquiring Lak or Tsez. How does a child determine which of two possible structures generates a given set of data? The learner's challenge is to avoid undergeneration in Lak-in particular, by making use of $\mathrm{A}^{\prime}$ operations in biabsolutives - and to avoid overgeneration in Tsez, by assuming that A'-extraction of the theme in biabsolutives is ungrammatical. In the final section of this paper, we outlined a possible strategy for the learner to derive the correct structure from the available data, as approximated from a corpus of child-directed Tsez speech. We hypothesized that a learner must be able to pair input data with a set of linguistic hypotheses about potential biabsolutive-generating structures in order to solve this learning problem. 


\section{References}

Aldridge, Edith. 2004. Ergativity and word order in Austronesian languages. Ph.D. dissertation, Cornell University.

Aldridge, Edith. 2008. Generative approaches to ergativity. Language and Linguistic Compass: Syntax and Morphology 2: 966-995.

Alexiadou, Artemis. 2009. On the role of syntactic locality in morphological processes: the case of (Greek) derived nominals. In Anastasia Giannakidou \& Monika Rathert (eds.) Quantification, definiteness and nominalization, 253-280. Oxford: Oxford University Press.

Asbury, Anna. 2008. The morphosyntax of case and adposition. Ph.D., Utrecht University.

Bach, Emmon. 1981. On time, tense, and aspect: An essay in English metaphysics. In Peter Cole (ed.). Radical pragmatics, 63-81. San Diego-New York: Academic Press.

Belletti, Adriana, and Luigi Rizzi. 1988. Psych-verbs and theta-theory. Natural Language and Linguistic Theory 6: 291-352.

Bobaljik, Jonathan. 2008. Where's Phi? Agreement as a post-syntactic operation. In Daniel Harbour, David Adger, and Susana Béjar (eds.) Phi theory: Phi-features across interfaces and modules, 295-328. Oxford: Oxford University Press.

Bokarev, Evgenij A. 1959. Cezskie (didojskie) jazyki Dagestana. Moscow: Izd. AN SSSR.

Bošković, Željko. 2007. On the locality and motivation of Move and Agree: An even 
more minimal theory. Linguistic Inquiry 38:589-644.

Bošković, Željko. 2014. Now I'm a phase, now I'm not a phase: On the variability of phases with extraction and ellipsis. Linguistic Inquiry 45: 27-89.

Burčuladze, G. T. 1979. Voprosy stanovlenija ličnogo sprjaženija v lakskom jazyke. Annuals of Ibero-Caucasian Linguistics VI: 176-246.

Bybee, Joan, Revere Perkins, and William Pagliuca. 1994. The evolution of grammar. Chicago: The University of Chicago Press.

Cezyas folklor [Tsez folklore]. 2003. Leipzig: MPI for Evolutionary Anthropology.

Cinque, Guglielmo. 2004. Issues in adverbial syntax. Lingua 114: 683-710.

Comrie, Bernard. 1997. Slogovaja struktura i fonologičeskie čeredovanija v cezskom jazyki (na materiale cebarinskogo govora). In Pamjati Georgija Andreeviča Klimova. Dagestanskij lingvističeskij sbornik, Vypusk 4, 63-65. Moscow: Academia.

Comrie, Bernard. 1999. Spatial cases in Dagestanian languages. Sprachtypologie und Universalienforschung 52: 108-117.

Comrie, Bernard. 2000. Valency-changing derivations in Tsez. In R.M.W. Dixon and Alexandra Y. Aikhenvald (eds.) Changing valency: Case studies in transitivity, 360-374. Cambridge: Cambridge University Press.

Comrie, Bernard. 2001. Vowel length and dialect variation in Tsez. In Chris SchanerWolles, John Rennison, and Friedrich Neubarth (eds.) Naturally! Linguistic studies in honour of Wolfgang Ulrich Dressler presented on the occasion of his 60th birthday, 81-86. Turin: Rosenberg \& Sellier. 
Comrie, Bernard, and Maria Polinsky. 1998. The great Dagestanian case hoax. In Anna Siewierska and Jae Jung Song (eds.) Case, typology and grammar: In honor of Barry J. Blake (Typological Studies in Language 38), 95-114. Amsterdam: John Benjamins.

Comrie, Bernard, and Maria Polinsky. 1999a. Form and function in syntax: Relative clauses in Tsez. In Michael Darnell (ed.) Functionalism and formalism in linguistics. Volume II: Case studies, 77-92. Amsterdam: John Benjamins.

Comrie, Bernard, and Maria Polinsky. 1999b. Possessor raising in a language that does not have any. In Doris L. Payne and Emmanuel Barshi (eds.) External possession, 523-542. Amsterdam: John Benjamins.

Comrie, Bernard, and Maria Polinsky. 1999c. Reflexivity in Tsez. In Ekaterina V. Rakhilina and Yakov G. Testelets (eds.) Typology and linguistic theory: From description to explanation, for the 60th birthday of Aleksandr E. Kibrik, 319-339. Moscow: Jazyki russkoj kul'tury.

Comrie, Bernard, and Maria Polinsky. 2002. The biabsolutive construction in Tsez. Paper presented at the Conference on Non-Slavic Languages of the Former Soviet Union, University of Chicago, May 2002.

Comrie, Bernard, Maria Polinsky, and Ramazan Rajabov. 1998. Tsezian languages. Ms., MPI and UCSD. (http://scholar.harvard.edu/mpolinsky/publications/tsezianlanguages-0)

Comrie, Bernard, and Helma van den Berg. 2006. Experiencer constructions in Dagestanian languages. In Ina Bornkessel, Matthias Schlesewsky, Bernard 
Comrie, and Angela D. Friederici (eds.) Semantic role universals and argument linking: Theoretical, typological, and psycholinguistic perspectives, 127-154. Berlin: Mouton de Gruyter.

Coon, Jessica. 2010. Complementation in Chol (Mayan): A theory of split-ergativity. Doctoral Dissertation, MIT.

Coon, Jessica. 2013a. Aspects of split-ergativity. New York: Oxford University Press.

Coon, Jessica. 2013b. TAM split ergativity. Language and Linguistics Compass 3, 171190.

Demirdache, Hamida and Miriam Uribe-Etxebarria 2000. The primitives of temporal relations. In Roger Martin, Don Michaels, Juan Uriagereka, and Samuel Jay Keyser (eds.) Step by step: Essays on minimalist syntax in honor of Howard Lasnik, 157-186. Cambridge, MA: MIT Press.

Denison, David. 1993. English historical syntax. New York: Longman.

Deo, Ashwini. 2009. Unifying the imperfective and progressive: Partitions as quantificational domains. Linguistics and Philosophy 32: 475-521.

de Swart, Henriette. 1998. Aspect shift and coercion. Natural Language and Linguistic Theory 16: 347-385.

Dowty, David. 1979. Word meaning and Montague grammar. Dordrecht: Kluwer.

El'darova, Roza G. 1995. Morfologija lakskogo glagola. Kandidatskaya dissertatsija. Dagestanskij Gosudarstvennyj Universitet, Makhachkala. 
Forker, Diana. 2009. The biabsolutive construction in Nakh-Dagestanian: A new type of object incorporation? Paper presented at the 8th Meeting of the Association of Linguistic Typology, UC-Berkeley.

Forker, Diana. 2012. The bi-absolutive construction in Nakh-Dagestanian. Folia Linguistica 46: 75-108.

Folli, Rafaella and Heidi Harley 2007. Causation, obligation and argument structure: on the nature of little $v$. Linguistic Inquiry 38: 97-138.

Fukuda, Shin. 2008. Two syntactic positions for English aspectual verbs. In Charles B. Chang and Hannah J. Haynie (eds.) Proceedings of the 26th West Coast Conference on Formal Linguistics, 172-180. Somerville, MA: Cascadilla.

Gagliardi, Annie and Jeffrey Lidz. 2014. Statistical insensitivity in the acquisition of Tsez noun classes. Language 90: 58-89.

Halle, Morris and Alec Marantz. 1993. Distributed morphology and the pieces of inflection. In Ken Hale and Samuel Jay Keyser (eds.) The view from building 20: Essays in honor of Sylvain Bromberger, 111-176. Cambridge, MA: MIT Press.

Harley, Heidi. 2009. Morphology of nominalizations and the syntax of vP. In Anastasia Giannakidou and Monika Rathert (eds.) Quantification, definiteness and nominalization, 320-342. Oxford: Oxford University Press.

Harris, Alice C. 2002. Endoclitics and the origin of Udi morphosyntax. Oxford: Oxford University Press.

Harris, Alice C., and Lyle Campbell. 1995. Historical syntax in cross-linguistic perspective. Cambridge: Cambridge University Press. 
Haspelmath, Martin. 1993. A grammar of Lezgian. Berlin: Mouton de Gruyter.

Imnajšvili, David S. 1963. Didojskij jazyk v sravnenii s ginuxskim i xvaršijskim jazykami. Tbilisi: Izd. AN Gruzinskoj SSR.

Jespersen, Otto. 1909-1940. A modern English grammar on historical principles. London: Allen and Unwin.

Kazenin, Konstantin I. 1998. On patient demotion in Lak. In Leonid Kulikov and Heinz Vater (eds.) Typology of verbal categories, 95-115. Tübingen: Niemeyer.

Kazenin, Konstantin I. 2013. Sintaksis lakskogo jazyka. Ms., Moscow.

Khaidakov, Said M. 1962. Laksko-russkij slovar'. Moscow: Gosudarstvennoe izdatel'stvo inostrannyx i nacional'nyx slovarej.

Khaidakov, Said M. 1966. Očerki po lakskomu jazyku. Moscow: Nauka.

Khalilov, Madjid. 1999. Cezsko-russkij slovar’. (Tsez-Russian dictionary). Maxachkala: Academia.

Kibrik, Aleksandr E. 1975. Nominativnaja/ergativnaja konstruktsija i logičeskoe udarenie $\mathrm{v}$ arčinskom jazyke. In Vladimir Zvegintsev (ed.) Issledovanija po prikladnoj $i$ strukturnoj lingvistike. Vol, 7, 54-62. Moscow: Moscow State University.

Kibrik, Aleksandr E. (ed.) 2001. Bagvalinskij jazyk: grammatika, teksty, slovari. Moscow: IMLI RAN Nasledie.

Kibrik, Aleksandr E. 2003. Konstanty i peremennye jazyka. Sankt-Peterburg: Aleteja.

Kibrik, Aleksandr E. and Sandro V. Kodzasov. 1988. Sopostavitel'noe izučenie dagestanskix jazykov: Glagol. Moscow: Izd. Moskovskogo universiteta. 
Kracht, Marcus. 2002. On semantics of locatives. Linguistics and Philosophy 25: 157232.

Laka, Itziar. 2006. Deriving split ergativity in the progressive: The case of Basque. In Alana Johns, Diane Massam, and Juvenal Ndayiragije (eds.) Ergativity: Emerging issues, 173-196. Dordrecht: Springer.

Larson, Richard. 1988. On the double object construction. Linguistic Inquiry 19: 335391.

Larson, Richard. 1990. Double objects revisited: Reply to Jackendoff. Linguistic Inquiry 21: 589-632.

Legate, Julie Anne. 2008. Morphological and abstract case. Linguistic Inquiry 39: 55101.

Lewis, M. Paul, Gary Simons, and Charles Fennig (eds.). 2013. Ethnologue: Languages of the world. $17^{\text {th }}$ edition. Dallas: SIL International.

Magomedova, È. K. 2008. Otglagol'nye substantivy v lakskom jazyke. Vestnik Stavropol'skogo gosudarstvennogo universiteta (filologičeskie nauki) 58: 46-52.

Magometov, Aleksandr A. 1965. Tabasaranskij jazyk: issledovanija i teksty. Tbilisi: Mecniereba.

Magometov, Aleksandr A. 1970. Agul'skij jazyk: issledovanija i teksty. Tbilisi.

Massam, Diane. 2001. Pseudo Noun Incorporation in Niuean. Natural Language and Linguistic Theory 19: 153-197.

Massam, Diane. 2009. Noun incorporation: Essentials and extensions. Language and Linguistic Compass 3-4, 1076-1096. 
McFadden, Thomas. 2014. Why nominative is special: stem-allomorphy and case structures. Paper presented at GLOW-37, Brussels.

Murkelinskij, Gadži B. 1971. Grammatika lakskogo jazyka. Fonetika i morfologija. Makhachkala: Dagestanskoe učebno-pedagogočeskoe izdatel'stvo.

Plaster, K., Polinsky, M., Harizanov, B. 2013. Noun Classes Grow on Trees: Noun Classification in the North-East Caucasus. Language Typology and Historical Contingency. Amsterdam: John Benjamins. 153-170.

Polinsky, Maria and Bernard Comrie. 2003. Constraints on reflexivization in Tsez. In Dee Ann Holisky and Kevin Tuite (eds.) Current trends in Caucasian, East European and Inner Asian Linguistics: Papers in honor of Howard I. Aronson, 265-289. Amsterdam: John Benjamins.

Polinsky, Maria, and Dan Jackson. 1998. Noun classes: Language change and learning. In Barbara A. Fox, Dan Jurafsky and Laura Michaelis (eds.) Cognition and function in language, 29-50. Stanford: CSLI.

Polinsky, Maria and Eric Potsdam. 2001. Long-distance agreement and topic in Tsez. Natural Language and Linguistic Theory 19: 583-646.

Polinsky, Maria and Eric Potsdam. 2002. Backward control. Linguistic Inquiry 33: 245282.

Polinsky, Maria, Carlos Gómez Gallo, Peter Graff, and Ekaterina Kravchenko. 2012. Subject preference and ergativity. Lingua 122: 267-277.

Preminger, Omer. 2009. Breaking agreements: Distinguishing agreement and cliticdoubling by their failures. Linguistic Inquiry 40: 619-666. 
Preminger, Omer. 2011. Agreement as fallible operation. Ph.D. Dissertation, MIT.

Preminger, Omer. 2014. Agreement and its failures. Linguistic Inquiry Monographs 68. Cambridge, MA: MIT Press.

Radkevich, Nina. 2010. On location: the structure of case and adpositions. Ph.D. dissertation, University of Connecticut.

Radkevich, Nina, and Lauren Eby Clemens. 2013. Person hierarchy and structure dependence in Lak agreement. Paper presented at WCCFL 31, February 8, 2013, Tempe, AZ.

Rudnev, Pavel. 2012. Matrix constituent interrogatives in Avar. Paper presented at the conference "Typology, Theory: Caucasus". Boğaziçi Üniversitesi, Istanbul, November 2012.

Spencer, Andrew. 2008. Does Hungarian have a case system? In Greville Corbett and Michael Noonan (eds.). Case and grammatical relations: studies in honor of Bernard Comrie. 35-57.

Sylak, John. 2008. Lak verbal morphology. B.A. Thesis, University of Chicago.

Takahashi, Masahiko. 2012. On restructuring infinitives in Japanese: adjunction, clausal structure, and phases. Lingua 122: 1569-1595.

Taylor, Barry. 1977. Tense and continuity. Linguistics and Philosophy 1: 199-220.

Torres Cacoullos, Rena. 2012. Grammaticalization through inherent variability: The development of a progressive in Spanish. Studies in Language 36: 73-122

Trommer, Jochen. 2008. Case suffixes, postpositions and the phonological word in Hungarian. Linguistics 46.2: 403-438. 
Vendler, Zeno. 1967. Verbs and times. Linguistics in philosophy, 97-121. Ithaca, NY: Cornell University Press.

Vlach, Frank. 1981. The semantics of the progressive. Syntax and Semantics 14:271-292.

Wolfram, Walt. $1980 a$-Prefixing in Appalachian English. In William Labov (ed.) Locating language in time and space, 107-142. New York: Academic Press.

Woolford, Ellen. 2006. Lexical case, inherent case, and argument structure. Linguistic Inquiry 37: 111-130.

Wurmbrand, Susi. 2001. Infinitives: Restructuring and clause structure. Berlin: Mouton de Gruyter.

Wurmbrand, Susi. 2004. Two types of restructuring: Lexical vs. functional. Lingua 114: 991-1014.

Wurmbrand, Susi. 2013. The features of voice. Handout of the talk, October 26, 2013, Little v Workshop, Leiden University, Holland.

$\mathrm{Xu}$, Fei, and Joshua Tenenbaum. 2007. Word learning as Bayesian inference. Psychological Review 114: 245-272. 


\section{Acknowledgments}

The authors of this paper are listed in alphabetical order. The work presented here was supported in part by an NSF GRF and an NSF-NEH DEL Postdoctoral Fellowship (FN50102-12) to Annie Gagliardi; by the Harvard College Research Program research fellowship through the Dunwalke Fund to Michael Goncalves; and by grants from the Davis Center for Russian and Eurasian Studies at Harvard, Max-Planck Institute for Evolutionary Anthropology, and NSF (SBR-9220219, BCS-0131946, and BCS-1144223) to Maria Polinsky. Any opinion, findings, conclusions or recommendations expressed in this material are those of the authors and do not necessarily reflect the views of the National Science Foundation, the United States Government, or other agencies.

We are grateful to our language consultants: Zalmu Abburahmanova, Alexei and Džamilya Džabrailovs (Lak) and Arsen Abdulaev, Paxruddin Magomedinov, and Ramazan Rajabov (Tsez). For helpful discussions of this project, we are also grateful to Dunstan Brown, Marina Chumakina, Bernard Comrie, Amy Rose Deal, David Erschler, Bradley Larson, Jeffrey Lidz, Keith Plaster, Omer Preminger, Peter Sells, Jakov Testelets, three anonymous reviewers, and the audiences at ALT 10, the Chicago Linguistic Society, Cornell University, Cambridge-York Comparative Syntax Workshop, and Surrey Morphology Group. 